ON THE

\title{
CONCLUSIONS DERIVED FROM THE EXPERIENCE OF RECENT STEAM BOILER EXPLOSIONS.
}

\author{
By Mr. EDWARD B. MARTEN, OF STOURBRIDGE.
}

The records of Steam Boiler Explosions in recent years are very numerous, as the increased attention drawn to the subject in this and other countries has placed far more information at disposal; and the experience of the last four years, since a former paper was read by the writer on the subject of boiler explosions, has confirmed the opinion then expressed, that all boilers, however good in original construction, are liable in the course of time to get into bad order and explode. The particulars of the explosions during this period are given in the Tables appended to the present paper, which show the number of explosions due to each cause in each class of boiler, distinguishing those of the United Kingdom from those in foreign countries. An analysis is also given of the explosions in the last four years, showing the canses of explosion of each form of boiler; and also a summary of the causes of explosion under the three general heads of-(1) faults in construction or repair: (2) faults in working which creep on insidiously and unnoticed: (3) faults which might be seen and guarded against by careful attendants. Nearly all of the faults in these three classes would have been detected by periodical examination.

In the case of Cornish, Lancashire, and other boilers with internal flues, the faults of construction which bave caused explosions have been weakness in the tubes, combustion chambers, ends, domes, or manholes ; and explosions in these, as in other classes of boilers, have also resulted from external or internal corrosion, shortness of water, undue pressure of steam, and scale or mud on the boiler plates. 
In plain cylindrical boilers, and others without internal fines, explosions have resulted from the boiler ends being made flat, and also from frequent repairs producing seam rips, especially in boilers having the plates arranged lengthways instead of in rings.

In marine boilers, weak flues and weak ends have also led to explosion, in addition to the other causes mentioned above.

Locomotive boilers have in two cases exploded in consequence of the strains thrown upon them by their being used as a frame for the engine.

Other explosions have resulted from want of stays, and from too much heat impinging on some particular part; and in domestic boilers from freezing of pipes under pressure.

Altogether the total number of explosions in this country that have been recorded during the past four years has amounted to 219 , which may be classed under the following heads :-

Faults of construction or repair .' . . . . . . . . . . . 95

Faults to be detected only by periodical examination . . . . . 62

Faults which should be prevented by careful attendants . . . . 54

Extraneous or uncertain causes . . . . . . . . . . . . 8

Total $\overline{219}$

By these 219 explosions 315 persons were killed and 450 injured.

The following are the particulars of the construction of the 219 exploded boilers :-

Cornish, Lancashire, or other boilers with internal flues . . . . 84

Plain Cylindrical boilers or others without internal flues . . . 54

Marine boilers . . . . . . . . . . . . . . . . . . 12

Agricultural boilers . . . . . . . . . . . . . . . . . 11

Locomotive boilers . . . . . . . . . . . . . . . . 10

Furnace-upright boilers . . . . . . . . . . . . . 8

Crane boilers . . . . . . . . . . . . . . . . . . . 6

Rag steamers, \&c. . . . . . . . . . . . . 6

Balloon and Elephant boilers . . . . . . . . . . . 5

Domestic boilers, \&c. . . . . . . . . . . . . . . . . 16

Not sufficiently described $\quad . \quad . \quad . \quad . \quad . \quad . \quad . \quad . \quad . \quad 7$

Total 219 
The causes of these 219 explosions may also be classed as follows :-

Worn out, corroded, or burnt plates . . . . . . . . . . . 89

Undue pressure, overloaded valves, intentional or from carelessuess 25

Bad construction, defective fittings or stays, or want of repair . 69

Shortness of water, formation of scale or mud, or external flues set too high . . . . . . . . . . . . . 28

Extraneous or uncertain causes. . . . . . . . . . . . . 8

Total. 219

Sketches of the most instructive examples of boiler explosions during the last four years are shown in the accompanying diagrams, Plates 52 to 61, which are sufficient to explain themselves, with a brief reference to their special features.

Although the importance of periodical examination as the best safeguard against explosion is generally admitted, a great number of those who make or use boilers have not at present sufficient belief in its importance to adopt this course. Boilers are still constructed. or set in such a manner as to render examination next to impossible; and are continued to be worked without making it the daty of those who mind them, or of any one else, to examine every part at frequent intervals; and hence such explosions have occurred as shown in Fig. 1, Plate 52, in which the original position of the boiler before explosion is indicated by the dotted lines. It is thought by many steam users that all has been done which is possible, if their boilers are the best that can be procured, and are set in the most approved way; and it is taken for granted that such boilers should last for many years, under the idea that a good boiler can never explode unless the feed is neglected. Similar boilers are often referred to as having worked safely for ten or twenty years, but it is forgotten that they may be exposed to the insidious action of furrowing on the inside or channelling on the outside, such as caused the explosions of the originally good boilers shown in Figs. 2, 3, 4, and 5 , Plate 52.

Much mischief arises from special classes of boilers, fittings, or apparatus, being looked npon as promising permanent safety from 
explosion; while the inevitable circumstance is overlooked that it is only so long as everything is maintained in good condition that safety is ensured. An apparatus, for instance, for preventing explosion from shortness of water or over-pressure, however perfect for any such object, wonld be quite inefficient as a safeguard against explosion from corrosion, furrowing, channelling, or weak construction. It is curious to note how often it is the case that every other part of an establishment is subject to severe and perpetual scrutiny; the engines especially being overhauled with the most scrupulous regularity; while the boilers, the very source of the power and the heart of the whole business, are left to themselves for long periods, even for years, without examination; and it is too often only after bitter experience that owners have understood the need of this examination. In this, as in many other matters, experience has shown that there is no royal road to safety, and that immunity is only secured by unremitting care and constant watchfulness. It should never be forgotten that even a good boiler can explode; for however 'good at the outset, sooner or later the time must eventually arrive, when such wear and tear will have taken place as will result in dangerous weakness, unless the boiler is carefully and systematically attended to. Although a boiler may even last safely for ten to thirty or more years if worked slowly and with care, no confidence can be placed in a boiler which has worked so long, unless it is examined in every part.

The opinion is more general than many are aware of, that explosions as a rule are caused by shortness of water and the sudden turning on of the feed water upon red-hot plates; and the appearances of injury in the plates from fire, arising in the ordinary course of working, have been frequently mistaken for signs of overheating from shortness of water at the time of explosion, as illustrated in Figs. 6 and 7, Plate 53. Although boilers do explode from the softening of the plates by overheating in consequence of shortness of water, yet it is very doubtful whether the turning on of the cold water at such a time is ever the canse of explosion. The feed water being always introduced at the bottom of the boiler, as in Figs. 8, 9, and 10, Plate 53, cannot be scattered 
suddenly near the overheated parts, but must rise gradually up the sides; and the boiler would have gone to pieces from the giving way of the softened parts long before the water reached them, as was the case in the explosions shown in Figs. 11 and 12, Plate 54. The experiment of injecting cold water into red-hot boilers has been carefully tried more than once, without producing any explosion.

Although it may be too much to suppose that boiler explosions will ever be entirely prevented, it is important that those who have the care of boilers should understand better what are the true causes of explosion, in order that they may know what to guard against in addition to shortness of water. This better understanding of the subject has been much retarded by the supposition that the causes of boiler explosions are beyond the comprehension of the boiler minders; and still more by the important differences of opinion armong those under whom they work. Much evil has resulted from the promulgation of strongly expressed views, which have been founded upon facts but of too limited extent, and such as must become modified by consideration of the facts of a large number and variety of explosions. Mysterious theories to account for explosions have been resorted to only from want of clearer explanations.

Before considering in detail the causes of explosion, it is necessary to recall to mind that beyond question there is sufficient accumulated force in any working boiler to cause all the violent effects of an explosion, if this force be suddenly liberated. In Figs. 13 and 14, Plate 54, are shown the violent effects of the rupture of vessels employed for steaming rags, which were filled with steam only. In ordinary boilers however there is present, besides the steam, a quantity of water heated much beyond the atmospheric boiling point; and when rupture takes place and the pressure is suddenly relieved, part of this water evaporates, and keeps up the supply of steam to continue the rupture and destruction. The explosion of a boiler differs from the discharge of electricity or lightning, which cleaves the air and instantly leaves a vacuum; it also differs from the discharge of detonating compounds which act suddenly and leave a vácuum; but it more nearly resembles the discharge of ganpowder, which burns sufficiently slowly to keep up 
a continuous pressure behind a projectile until it leares a gun; and each cubic foot of water in a boiler working at $60 \mathrm{lbs}$. pressure has been shown to produce in steam an explosive effect equal to one pound of gunpowder. None of the elaborate but unlikely theories of decomposed steam, or of electric accumulations, suppose a force so fitted to cause destruction as that contained in the highly heated water existing in all working boilers.

The following appear to be the general results to be derived from the experience of the explosions in this country during the last four years.

First as to faults of construction which fall under the department of the boiler maker or repairer. One of the most apparent causes of explosion in stationary boilers is the loss of strength occasioned by frequent repair, not only from the injury done to the old plates by removing rivets, but from the want of bond in the new work. This has led to many of the explosions of the Plain Cylindrical boilers, such as are shown in Figs. 15, 16, and 17, Plates 54 and 55. Where the plates are arranged longitudinally instead of in rings, the danger is increased, as there is less chance of a dangerous rip being arrested by a crossed joint. So great a number of boilers with continuous longitudinal seams, especially in the North, have worked for twenty or thirty years, that it can hardly be supposed they are any weaker than the boilers made in rings; but they are more liable to explode, for if a seam rip occurs, it more easily extends along the seam, and leads to the general break up of the boiler, as shown in Fig. 18, Plate 55.

Perhaps no boilers have worked for a greater number of years than the Plain Cylindrical boilers, many specimens being in existence and apparently in good order which were put to work fifty or sixty years ago. When such boilers have been too much or injudiciously repaired, they are treacherous and uncertain; but their rupture and explosion occur not so much on account of fault of shape, as from the simple reason that like willing horses they are easily overworked. The grates are usually twice as large as the fair proportion to the heating surface, producing the double evil of 
forcing more heat through the iron plates over the fire than they can transmit without injury, and allowing a great amount of heat to pass away to the chimney without useful effect. Careful experiment shows that nearly as good duty can be obtained with the plain cylindrical boiler as with any other form, provided the rate of combustion is in fair proportion to the extent of heating surface in the boiler. The circumstance that many plain cylindrical boilers have exploded is not sufficient to condemn this make of boiler, which is the cheapest, simplest, and most easily set. If the number of explosions alone were to be taken as the guide, it would lead to the condemnation of the Cornish and Lancashire boilers, from the experience of the past four years. But in the case of both plain cylindrical and other forms of boilers, most of the dangers admit of remedy, and can be guarded against by frequent examination.

Five very fatal explosions have occurred of boilers heated by Puddling and Mill Furnaces, leading in some cases to the supposition that this form of boiler is more liable to explosion than others. They were not adopted however in the iron-making districts without great care and consideration, and there does not seem ground for attributing special danger to them: The causes of the five explosions referred to of these boilers were manifest, and would have led to the explosion of any form of boiler; the loss of life however was great, because the situation of the boilers was among a large number of workmen. The steam power required in ironworks so far exceeds that in any other trade that an ironwork is half composed of boilers; the workmen are necessarily within the range of explosion of many boilers, and hence the great loss of life when such an accident occurs. The explosions of such boilers shown in Figs. 19 and 20, Plate 55, were from external and internal corrosion respectively of the bottoms, rendering them too weak to bear the ordinary pressure. Those shown in Figs. 21 and 22, Plate 56, were from the collapse of the central tubes, which were weakened by external and internal corrosion respectively. In Fig. 24, Plate 57, the shell was in bad order from over work and receiving too much heat from four large furnaces, one of these especially causing a constant mass of flame to impinge upon a single plate, which resulted in a seam rip. 
The greatest number of explosions and the greatest loss of life and personal injury have been in the case of Cornish and Lancashire boilers or others with internal flues. In the county of Cornwall itself there have been many explosions, as often from the rupture of the shell, Fig. 23, Plate 56, as from the collapse of the tube, Fig. 25, Plate 57. The temporary patching on some of these old boilers was most extensive, Fig. 26, and the only wonder really was that they held together as long as they did. The belief that shortness of water is the only cause which can lead to the collapse of tubes is so strong, that the boiler minders have often been condemned almost unheard in cases of explosion, as if there were no room for doubt that their neglect was the cause. Explosions from weakness of tubes are not however confined to Cornwall, as for example in Fig. 27, where the flue was oval and very weak: althongh it was supposed that shortness of water cansed the accident, from the idea that nothing else could account for it. The strain caused by the varying temperature of the internal tubes in Cormish or Lancashire boilers, and the difficulty of staying their flat ends so as to make them sufficiently secure without being too rigid to allow for the expansion of the tubes, render them liable to corrosion or "furrowing" in particular lines of strain, the destructive action of which is very rapid; while the large quantity of brickwork around the outside, necessary to form the external flues, also renders them liable to corrosion in the parts most difficult of access. In this favourite form of boiler therefore careful and frequent examination in every part is more needed than in boilers of simpler form and setting; and the increasing number of explosions among these boilers seems to establish that they are only trustworthy if frequently examined and kept in perfect order.

Several instances have occurred of explosion of Portable Crane Boilers. Their small size has led to their condition being disregarded, under the idea that scarcely any pressure could burst them. In practice it is found however that they are often exposed to greater pressure than other boilers, because the fire is large and quick in proportion to their size; and they often have to stand for a considerable time with the steam up, and their exposed position and 
long intervals of rest add to the chances of corrosion, as shown by the example in Fig. 28, Plate 58. The large manholes without strengthening rings, that are so often put in these boilers, bave been the cause of explosions such as that shown in Fig. 29. The same remark applies to some of the portable or agricultural boilers which have exploded, such as those shown in Figs. 30 and 31 .

Much mischief is often caused by bad imitation of well planned boilers. Thus in boilers of the Cornish form, the ends are made sometimes so rigid as to give no allowance for the expansion of the tube, and the result is such continued strain as to cause constant leaking and the consequent risk of fracture. In furnace boilers the tops of the crowns of the inside tubes are often made flat, as in Fig. 37, Plate 59, instead of being domed; or the inside tube is of undue size, as in Fig. 21, Plate 56. Furnace boilers have been made with the omission of the stays that are so peculiarly necessary in that form, whereby both ends have been left free to bulge outwards with the pressure, as in Fig. 32, Plate 58.

Cornish boilers are often altered to the plain cylindrical form, without compensation being made for the loss of strength caused by the removal of the tube; this has led to such explosions as shown in Fig. 33, where two tubes were taken out, and Fig. 34, where one tube was taken out. One of the most freqnent and serious causes of loss of strength is the repairing of externally fired boilers. Not only are the patches sometimes only bolted on in a temporary manner, as in Fig. 35, Plate 59, but even where they are rivetted on there is an entire want of bond or crossed joint, as in the case of the exploded boilers shown in Figs. 15, 16, and 17, Plates 54 and 55, and Fig. 36, Plate 59.

An attempt is made in Fig. 38 to show the effect of wear and tear of boiler plate in an ordinary upright furnace boiler, such as is shown in Fig. 37. The external surface is exposed to intense heat and consequently expands, while the internal surface is kept cool by contact with the water and expands to a much less degree. The continued repetition of this process produces the same effect of cracking the surface as that seen in the anvil blocks of steam hammers; and the strength of the plate is reduced in proportion to 
the destruction of the continuity of its surface. The deleterious effect of this process is much increased if the boiler is subject to alternate heating and streams of cold air on opening the fire-doors. To avoid it the flame should have room to spread over as large a surface as possible, without impinging on one particular point, and the firing should be as regular as possible; and hence the greater freedom from injury in boilers mechanically fired or heated by gas. The above action is quite distinct from the overheating of the plates that occurs when no water is in contact with them, which simply softens them and reduces their strength, as in Fig. 39. It is believed that many boilers suffer from overheating without being short of water : and an attempt is made to show this action in such an upright boiler as is represented in Fig. 37, by the enlarged section of the side shown in Fig. 40. The flame is shown impinging on a limited surface, as before, and the steam rises so rapidly from the inner surface as to maintain a continuous stratum of steam between the iron and the water, and the plate consequently becomes overheated at that part. When the intense flame subsides by an alteration of the working of the furnace, the stream of steam diminishes, and the water returns and suddenly cools and contracts the plate, but often not before it has commenced to get out of shape. This has perhaps led to the explosion shown in Fig. 59, Plate 61. The same thing may happen to the crowns of tubes of internally fired boilers when over fired, as in Fig. 41, Plate 59. Success has attended the use of internal linings to boilers, arranged so as to ensure a rapid circulation over the most heated parts, and also to catch all the mud and loose scale.

In order to enable boiler minders to make proper periodical examinations, it is necessary that care should be taken to arrange both the boilers and the flues with that view; and this can be done without materially injuring the efficiency of the boiler. Ordinary plain cylindrical boilers can be entered easily, as in Fig. 42, Plate 60; and although the small spaces between the tubes and the shells of Cornish and Lancashire boilers, as shown in Fig. 43, render the complete examination troublesome, there is no difficulty in seeing those parts most likely to need examination, such as the crowns of 
the tubes and the end plates and angle iron. It is in the external flues that greater accommodation is needed, as in many cases these are so narrow that the boiler is quite inaccessible without pulling down the brickwork, as in Figs. 44 and 45 . The loss of heating effect caused by the use of wider flues is so little, that it is far outweighed by the greater security obtained from the more efficient examination that is thereby rendered practicable. The flues of the plain cylindrical boiler are easily made wide enough for a man to pass through them. The flues of Cornish and Lancashire boilers should be made as shown in Figs. 46 and 47, so that a man can enter them without such inconvenience as in Fig. 48. One point of danger being the use of wide mid-feather walls, on which corrosion is apt to take place, these should be narrowed and the weight of the boiler supported on side brackets; the top of the mid-feather and side walls can then be constructed with sight-holes as at $A \mathrm{~A}$ in Figs. 49 and 50 , so as to give the means of examining the plates near each seam by simply removing loose bricks.

The explosions of fourteen Domestic or Heating-Apparatus Boilers are included in the list of explosions, Table III ; and some notice is required to be taken of these, because they have led to the loss of the lives of those who could not be expected to know their construction or how to guard against accident; and as these boilers are seldom seen or examined after they are once set, they should be the more carefully constructed. In one or two cases these boilers were of a rectangular shape, as in Fig. 51, Plate 61, ill adapted to bear internal pressure, and yet placed in connection with cisterns in the roofs of lofty houses, so as to expose them to a hydrostatic pressure almost up to their bursting strength without any addition of steam pressure. The most usual cause of explosion is the lighting of the fire during frosty weather in a house that has been left vacant, so that steam pressure accumulates in the boiler whilst the exit is frozen up, as was the case in Fig. 52. The cast-iron boilers commonly used, Fig. 53, are capable of bearing but little pressure; and the wroughtiron boilers, as in Fig. 54, are found often so badly welded as to be but little stronger; but even if they were as strong as they could be made, the stoppage of the pipes by ice would lead to explosion. Steam 
pressure may be guarded against by a safety valve; but as this may become set fast in a little time, it would be far better to aroid all chance of steam accumulation by such an arrangement as that shown in Fig. 55, where the circulating boiler is placed within an open-topped boiler behind the kitchen fire, and only receives its heat through the hot water surrounding it, and therefore cannot itself become sufficiently hot to generate steam.

A few remarks may be useful as to those faults arising in working which fall under the department of the boiler minders. Not a few of the explosions during the last four years have occurred from acts of simple carelessness, such as where a blow-off pipe was left open, so that the boiler was nearly emptied of water while at work; or in another case where two boilers were fed at the same time through a common pipe without a back valve, and the water from one "kicked" over into the other. Undue pressure has been allowed to accumulate by safety valves being tied down, as in the agricultural boiler, Fig. 56, Plate 61 ; or by an extra weight being put upon the safety valve, as in an instance where three bricks were fastened to the lever and the fires were lighted earlier than usnal, nnder the idea that an accumulation of steam conld be raised during the night to make a good start in the morning. Another explosion was caused by working a boiler at more than three times its proper pressure to meet a temporary emergency. In not a few cases of explosion there was no pressure gauge on the boiler, or the gange was out of repair in consequence of being placed on the steam pipe, so that it vibrated with every stroke of the engine; as in the examples shown in Figs. 24 and 16, Plates 57 and 54.

Corrosion has been the direct canse of many of the explosions. In one or two cases the corrosion was known to exist, but the renewal of the boiler was too long delayed, as in Fig. 57, Plate 61; in others it took both owners and minders by surprise, as in Fig. 1, Plate 52. It is said that to produce rapid rusting of iron there must be present oxygen, water, and carbonic acid; and as all these are present in a boiler flue when there are leaks, it is not surprising that so many cases occur of explosions from corrosion. 
Much mischief is often done by the injudicious use of compositions in the boiler that are designed to prevent incrustation, especially where there is no blow-off cock or where its use is neglected. A hard deposit on the boiler plates is, in the writer's opinion, not so injurious as the soft and muddy deposit produced by the use of such compositions. A hard scale is equivalent to thickening the plate; and althongh this is sufficiently mischievous, the injury to the plates is much more rapid when a thicker but spongy deposit entirely prevents contact of the water and impedes the transmission of the heat. An attempt to illustrate this is given in Fig. 58, Plate 61, which is an enlarged view of a portion of such a boiler as is shown in Fig. 37. The money spent in boiler compositions would be better applied in securing a supply of proper water, or in filtering and purifying the water before it enters the boiler.

The writer bas had to mention only faults in boilers; but it is not to be inferred that all boilers are working in actual danger. A very small percentage perhaps are so; but without periodical examination no one can feel sure of the condition of any boiler. It is not likely that explosions in future will be from exactly the same causes as those now described, because the known faults will be avoided. For instance no new Balloon, Wagon, or Butterley boilers are now made; and the peculiar faults and the weakness of the tubes in Cornish and others of the better classes of boilers are now so well known as to be generally avoided; and as information spreads, many evils will become things of the past.

As periodical examination has been so strongly adrocated, it might seem natural to desire that it should be enforced by government authority; but this is by no means recommended. A select parliamentary committee has been recently investigating the subject, with a view to ascertain whether that would be desirable, but has adjourned for the session without coming to any decision on this point. Even if a perfect system of government inspection could be contrived and perfectly administered, it would have the effect of taking the responsibility from the owners, who are the natural guardians of the safety of their boilers. Although the loss of 70 lives 
per annum by boiler explosions is sufficiently deplorable, the deaths by railway accidents are more than three times that number; yet very little inspection of railways is held to be necessary, and that inspection takes place chiefly before the commencement of working or after accidents. A coercive system may introduce more evils than it cures, especially as at present so much difference of opinion exists respecting the causes of boiler explosions. In the opinion of the writer, far more real good arises from the calm discussion of the facts and from the spread of correct information by such societies as this Institution, than from enforcing by law any action which is not perhaps believed by the majority of steam users to be at all necessary or useful. It has been at times suggested to increase the power and responsibility of coroners in holding inquests upon those killed by boiler explosions, by requiring them to obtain scientific evidence and to insist that the causes of the explosions shall be added to the verdicts of juries. But it is believed that this would only encumber an important institution, because a jury who might well decide whether a person had been killed by any criminal carelessness would not be a suitable tribunal to decide between possibly conflicting scientific evidence; and also, as an inquest may result in a verdict of manslaughter, the eliciting of information on such an occasion is checked by the natural fear of inadvertently involving some one in so serious a charge. The public at large, and steam users generally, would gain more information and guidance from the scientific evidence itself than from the verdict of a coroner's jury; and it is believed much good has resulted in preventing locomotive boiler explosions by publishing the reports of the government inspecting engineers, who have gained their knowledge of the facts in conversation with all those concerned, and have added recommendations which have been promptly acted upon.

The writer's object has been that the boilers found most convenient and best suited for the different purposes for which they are used should be made to work with safety, rather than that reliance should be placed upon the qualities of any particular kind of boiler or fittings. No form of boiler at present admits of absolute reliance upon its freedom from risk. 
The following general conclusions appear to arise from the consideration of the records of boiler explosions.

1. That the force accumulated in an ordinary boiler is enough to account for the violence of an explosion.

2. That no form of boiler, however well constructed and fitted, is free from the liability to explosion, if allowed to get out of order; and that boilers which bear the hydraulic test may still be dangerous.

3. That the condition of a boiler can be satisfactorily ascertained only by periodical examinations, and that no boiler should work without being thoroughly examined at short intervals.

4. That the cost of periodical examination is so little as to be far outweighed by the greater security obtained; and that the settings of all boilers should be constructed with a view to facilitate examination.

5. That the surest way to make systematic examination general is to spread as widely as possible correct information as to the facts and ascertained causes of boiler explosions, and to inform boiler owners and minders what dangers to guard against; and that this is preferable, and more likely to lessen explosions than enforcing any system of inspection by legal enactment. 
TABLE I.

Summary of Records of Steam Boiler Explosions

up to 30 th June 1870 ,

showing Description of Exploded Boilers.

\begin{tabular}{|c|c|c|c|c|c|c|c|c|c|}
\hline \multirow{2}{*}{ Description of Boilers. } & \multicolumn{3}{|c|}{ Explosions up to Jane 1868.} & \multicolumn{3}{|c|}{$\begin{array}{l}\text { Explosions in the } 4 \text { years } \\
\text { from June } 1866 \text { to June } 1870 .\end{array}$} & \multicolumn{3}{|c|}{$\begin{array}{l}\text { Total Explosions } \\
\text { up to June } 1870 \text {. }\end{array}$} \\
\hline & English. & Foreign. & 'Total. & English. & Foreign. & Total. & English. & Foreign. & Total. \\
\hline Marine . . . . . . . . . & 57 & 263 & 320 & 12 & 64 & 76 & 69 & 327 & 396 \\
\hline Cornish, Lancashire, or others with internal flues & 140 & 1 & 141 & 84 & 3 & 87 & 224 & 4 & 228 \\
\hline Locomotive . . & 91 & 29 & 120 & 10 & 68 & 78 & 101 & 97 & 198 \\
\hline Plain Cylindrical externally fired. . & 114 & 2 & 116 & 54 & 3 & 57 & 168 & 5 & 173 \\
\hline $\begin{array}{l}\text { Balloon, Haystack, Wagon, Butterley, British- } \\
\text { Tube, Elephant, or Trevithick . . . . . }\end{array}$ & 62 & 2 & 64 & 5 & 2 & 7 & 67 & 4 & 71 \\
\hline Portable, Agricultural, Upright, Crane, or very small & 28 & 1 & 29 & 17 & 17 & 34 & 45 & 18 & 63 \\
\hline Heating, Kitchen, Domestic, Rag Steamers, \&c. . & 14 & ... & 14 & 22 & 14 & 36 & 36 & 14 & 50 \\
\hline Furnace-upright. . . . . . . . . . & 10 & ... & 10 & 8 & $\cdots$ & 8 & 18 & ... & 18 \\
\hline Not sufficiently described to be classified . . . & 203 & 29 & 232 & 7 & 175 & 182 & 210 & 204 & 414 \\
\hline Totals . . . . . . . . . & 719 & 327 & 1046 & 219 & 346 & 565 & 938 & 673 & 1611 \\
\hline
\end{tabular}


TABLE II.

Summary of Records of Steam Boiler Explosions

up to $30 t h$ June 1870,

showing Causes of Explosions.

\begin{tabular}{|c|c|c|c|c|c|c|c|c|c|}
\hline \multirow{2}{*}{ Causes of Explosions. } & \multicolumn{3}{|c|}{ Explosions up to June 1866.} & \multicolumn{3}{|c|}{$\begin{array}{l}\text { Explosions in the } 4 \text { years } \\
\text { from June } 1866 \text { to June } 1870 .\end{array}$} & \multicolumn{3}{|c|}{$\begin{array}{l}\text { Total Explosions } \\
\text { up to June } 1870 \text {. }\end{array}$} \\
\hline & English. & Foreign. & Total. & English. & Foreign. & Total. & English. & Foreign. & Total. \\
\hline Worn out, corroded, or burnt plates. . . . . & 92 & 53 & 145 & 89 & 5 & 94 & 181 & 58 & 239 \\
\hline $\begin{array}{l}\text { Undue pressure, overloaded valves, intentional or } \\
\text { from carelessness }\end{array}$ & 132 & 5 & 137 & 25 & 6 & 31 & 157 & 11 & 168 \\
\hline $\begin{array}{c}\text { Bad construction, weak tubes, defective fittings or } \\
\text { stays, or want of repair }\end{array}$ & 136 & 108 & 244 & 69 & 8 & 77 & 205 & 116 & 321 \\
\hline $\begin{array}{l}\text { Shortness of water, formation of scale or mud, or } \\
\text { external flues set too high }\end{array}$ & 106 & 8 & 114 & 28 & 2 & 30 & 134 & 10 & 144 \\
\hline Extraneous causes, lightning, fire, gas, \&c. . . & 6 & 3 & 9 & 2 & ... & 2 & 8 & 3 & 11 \\
\hline Too uncertain to be classified . . . . . . . & 247 & 150 & 397 & 6 & 325 & 331 & 253 & 475 & 728 \\
\hline Totals . . . . . . . . . & 719 & 327 & 1046 & 219 & 346 & 565 & 938 & 673 & 1611 \\
\hline
\end{tabular}




\section{TABLE III.}

Analysis of Steam Boiler Explosions in the United Kingdom during the Four years ending 30th June 1870, showing the Causes of Explosion of Boilers of different descriptions.

$\mathbf{A}=$ Fazlts in construction or repair.

$\mathbf{B}=$ Faults which should be detected by periodical examination.

$\mathbf{C}=$ Faults which should be prevented by careful attendants.

$\mathrm{D}=$ Causes extraneous or uncertain.

$\mathbf{E}=$ number of Explosions. $\mathbf{K}=$ number of persons Killed. $\mathbf{I}=$ number of persons Injured,

\section{Cornish, Lancashire, or other Boilers with internal flues.}

A

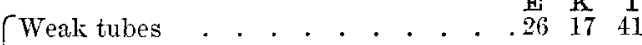

Weak combustion chambers . . . . . 5 87

Weak ends . . . . . . . . . 31010

Weak dome. . . . . . . . . . . 100

Weak manhole . . . . . . . . . 111

Bad repair . . . . . . . . . . . $35525 \mathrm{~K} I$

B $\left\{\begin{array}{l}\text { External corrosion } \\ \text { Internal corrosion }\end{array}\right.$ $\begin{array}{llll}39 & 41 & 61\end{array}$

C $\left\{\begin{array}{l}\text { Shortness of water } \cdot . \cdot . \\ \text { Scale or mud }\end{array}\right.$

Unduc pressure

Plain Cylindrical or other Boilers without internal flues.

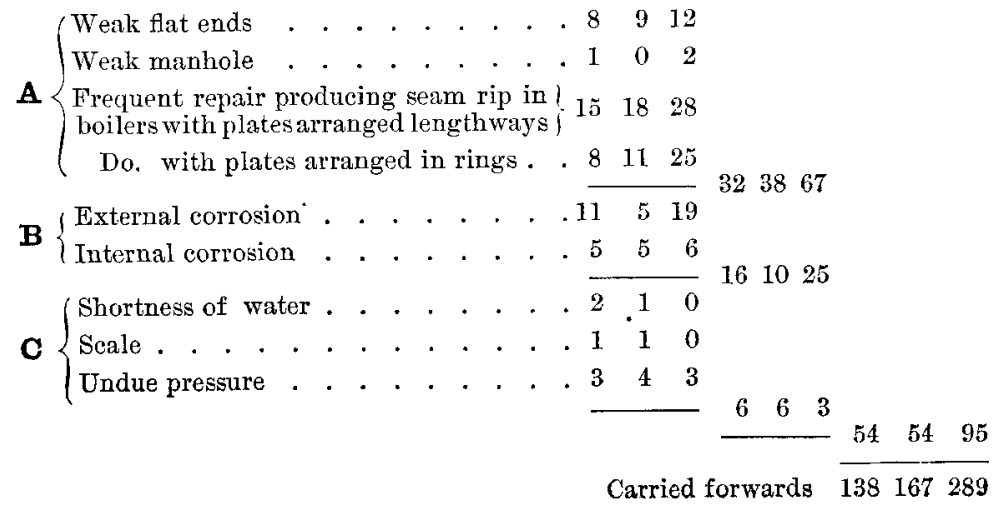


Marine Boilers. $\quad$ Brought forwards $\quad \begin{array}{cccc}\mathbf{E} & \mathbf{K} & \mathbf{I} \\ 167 & 289\end{array}$

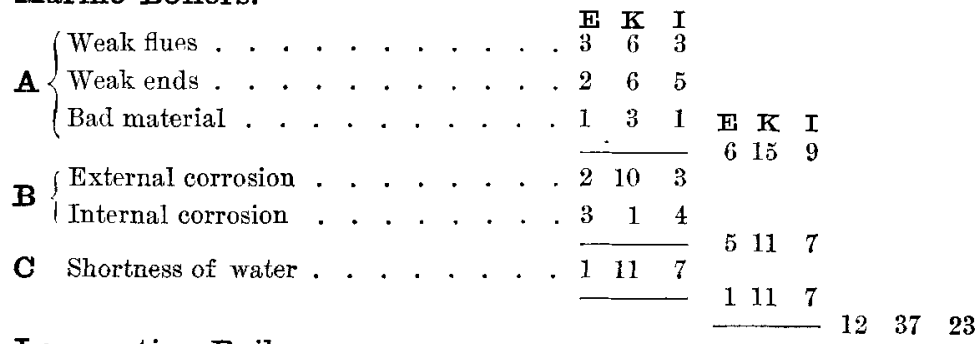

Locomotive Boilers.

A Boiler used as frame for engine $\quad$. . . $\begin{array}{lll}2 & 1 & 2\end{array}$

B $\left\{\begin{array}{l}\text { External corrosion } \\ \text { Internal corrosion }\end{array}\right.$

$2 \quad 1 \quad 2$

$\begin{array}{lll}4 & 1 & 7\end{array}$

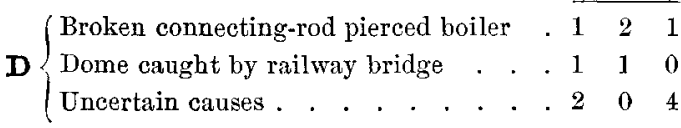

Agricultural Boilers.

A Weak manhole . . . . . . . . . . 114

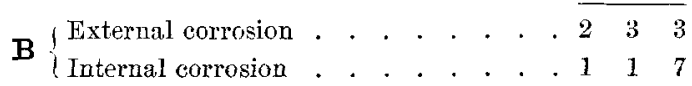

$1 \quad 14$

$\begin{array}{lll}3 & 4 & 10\end{array}$

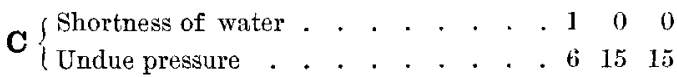

\begin{tabular}{lllll}
4 & 3 & 5 & & \\
\hline
\end{tabular}

\section{Furnace-upright Boilers.}

$\begin{array}{lll}11 & 20 & 29\end{array}$

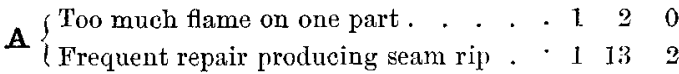
B $\left\{\begin{array}{l}\text { External corrosion . . . . . . . } 21311 \\ \hline\end{array}\right.$
B Internal corrosion . . . . . . . . 2156
C Shortness of water . . . . . . 338

\section{Elephant Boilers.}

A Weak ends or want of stays . . . . . 1122

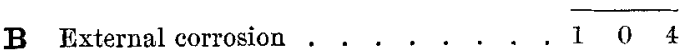


Crane Boilers.

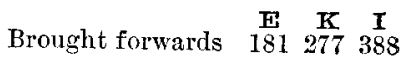

A Weak manhole E $\mathrm{K}$ I

B External corrosion $\underset{3}{\mathbb{7}} \underset{7}{\mathrm{~K}} \frac{\pi}{3}$

C Shortness of water. $1 \quad 4 \quad 2$

$\begin{array}{lllll}2 & 2 & 0 & 2 & 2\end{array}$

Rag Steamers, \&c.

C Undue pressure . . . . . . . . . 12126

Feed-water Heaters.

D Uncertain causes . . . . . . . . . 2006

Domestic Boilers.

200

A Weak shape . . . . . . . . 347

B Corrosion . . . . . . . . . . 200

C Undue pressure from freezing of pipes $\begin{array}{rrr}9 & 7 & 9\end{array}$

\section{Balloon Boilers.}

B External corrosion . . . . . . . . . 2 I 2

C Undue pressure . . . . . . . $\overline{110}$

\section{Boilers of uncertain description.}

A Weak manhole . . . . . . . . . . 100

(Steam entered through blow-off pipe $\begin{array}{llllll}1 & 1 & 2 & & & \end{array}$

C $\left\{\begin{array}{lllll}\text { Steam pipes broken . . . . . . . . . . } & 2 & 4 & 3\end{array}\right.$

Shortness of water . . . . . . . . 114

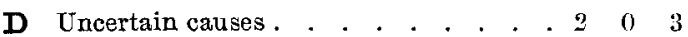


TABIE IV.

Summary of Causes

of the Steam Boiler Explosions comprised in Table III.

\begin{tabular}{|c|c|c|c|}
\hline Causes of Explosions. & $\begin{array}{c}\underset{\text { Number }}{\text { of }} \\
\text { Explosions. }\end{array}$ & $\begin{array}{c}\mathrm{K} \\
\text { Number of } \\
\text { persons } \\
\text { Killed. }\end{array}$ & $\begin{array}{c}I \\
\text { Number of } \\
\text { persons } \\
\text { Injured }\end{array}$ \\
\hline A Faults in construction or repair. & 95 & 128 & 167 \\
\hline $\begin{array}{c}\text { B Faults which should be detected by } \\
\text { periodical examination . . . }\end{array}$ & 62 & 105 & 185 \\
\hline $\begin{array}{c}\text { C Faults which should be prevented by } \\
\text { careful attendants. }\end{array}$ & 54 & 79 & 84 \\
\hline D Extraneous or uncertain causes. . . & 8 & 3 & 14 \\
\hline Totals. . & 219 & 315 & 450 \\
\hline
\end{tabular}

Mr. MARTEn exhibited an extensive collection of specimens of corroded plates from boilers that had exploded, showing the effects of external and internal corrosion under different circumstances; and specimens of plates that had been overheated, by the flame impinging too strongly upon a particular spot. He exhibited also a very extensive and interesting series of photographs of explosions, together with models of various constructions of boilers, and others illustrating some of the most destructive explosions.

The Chairman enquired what rules of strength were generally adopted at the present time in the construction of boilers.

Mr. Marten said be believed that in stationary boilers of 6 or 7 feet diameter, and working at an average pressure of 40 or 50 lbs., the general practice was to use plates about 3-8ths inch thick: there was not found to be much advantage in having them thicker, 
because the iron deteriorated more quickly in the thicker plates, from the heat passing less rapidly through them.

The Chatrman remarked that with those proportions the limit of strength of a boiler would be only about five times the strain it was subjected to in working, allowance being made for rivet holes; which seemed to leave rather a small margin of safety.

Mr. L. E. Fietcher was sure they must all feel much indebted to the anthor of the very interesting paper that had been read, for the great amount of light he had thrown upon a subject upon which not long ago there had been a great deal of mystery and confusion, steam boiler explosions having been attributed to various conjectural causes, such as magnetism, galvanism, and electricity. Such theories were now entirely dispelled, as shown by the present paper, which traced the explosions to their true causes; and he quite agreed with the views expressed, that all boiler explosions were to be attributed simply to neglect in some form or other. The whole of the results produced by a boiler explosion were due to the immense force of the steam pent up in the boiler, the amount of which had not been fully realised until recently. From the researches however of Rankine, Joule, and Airy, the amount of force that could be generated in a steam boiler was now capable of being measured; and according to Mr. Airy, one cubic foot of water heated to the temperature of steam at 60 lbs. pressure per square inch would develop, when suddenly liberated from pressure, as much force as $1 \mathrm{lb}$. or $2 \mathrm{lbs}$. of gunpowder. This amount of force was amply sufficient to account for all the disastrous effects attending a boiler explosion, and therefore all mysterious causes might be dismissed at once, and every explosion might be traced to neglect on the part of either the owner, the maker, or the minder of the boiler. It was very common to attribute explosions to the boiler minder, which was easily explained by the owner and maker combining to throw the blame upon the weaker party. He had found that for one explosion really due to the boiler minder six explosions were due to the maker or the owner, more frequently the latter. As to the explosions from malconstruction, most even of these he considered should be attributed to the owner rather than the maker, on account of the 
reluctance frequently met with to pay a proper price for a really good boiler. If good boilers were procured and were also well looked after in working, there would be an end to the terrible catastrophes hitherto occurring, for which he considered the boiler owners were really responsible. In the recent public investigations of the subject of boiler explosions, it had been admitted as now established that explosions could be prevented by means of proper examimation of boilers, by which any weak places could be found out in time to avert danger. The question remaining therefore to be decided was, how was the proper examination of boilers to be secnred throughout the country. This was required to be effected in such a manner as to suppress explosions but not to embarrass the users of steam; and he considered the best way would be to require by legislative enactment that every steam boiler should be periodically examined and certified as safe, and that no boiler should be allowed to be used which was not so. The actual examination however he thought had better not be in the hands of the Government, in order to avoid any risk of the freedom of steam users being unnecessarily restricted as to the construction of boiler employed.

With regard generally to the strength of boilers, he considered that a boiler of 7 feet diameter, made of plates 7-16ths inch thick with single-rivetted longitudinal joints, was safe to work at $60 \mathrm{lbs}$. pressure; double-rivetted it would be safe up to 70 or $80 \mathrm{lbs}$. For this pressure the furnace tubes of Cornish or Lancashire boilers should be strengthened with stiffening rings at all the circumferential seams of rivets. It was desirable that every boiler should be provided with two glass water-gauges, so that one might act as a check upon the correctness of the other; and the feed-pipe should always be furnished with a back valve, to prevent any risk of the furnace crowns being laid bare by the water escaping at the feed inlet into another connected boiler, or by leakage in the feed pipe. There should be two safety-valves, one to act in case either of over-pressure or of low water, while the other safety-valve should be of external dead-weight pendulous construction; there should also be a steam pressure-gauge to every boiler, and a blow-off cock at the bottom of the boiler. 
Mr. R. B. Longridae said he fully concurred in the main with the views advanced in the paper that had been read, and could confirm the statements as to the number of explosions and the causes of them. From the experience of the Association with which he was connected for the inspection and insurance of steam boilers, it had been found that nearly 30 per cent. of the explosions which occurred were to be attributed to negligence of the attendants, about 30 per cent. to wear and tear, and 40 per cent. to malconstruction. It had also been found that where boilers were periodically examined the risk of explosion was greatly reduced : taking the whole of the explosions that had occurred during the past eleven years, the proportion of explosions had only been $I$ in every 4,600 of the boilers that were periodically examined, while of boilers that were not inspected the number of explosions during the same period was 1 in every 2,000. The explosions which had occurred during the same period among the boilers that were insured had included. 10 plain cylindrical boilers and 10 Cornish boilers; but as the plain cylindrical boilers were only 15 per cent. of the entire number, while the Cornish were about 75 per cent., the result was very much in favour of the Cornish boilers, the safety of these being thus shown to be practically five times that of the plain cylindrical boilers, whereas the opinion expressed in the paper had been that the latter were much the safer. In regard to the remark which had been made as to the comparatively small number of explosions that were really due to the negligence of the attendants, his own experience had led him to quite a different conclusion, as he had found that 30 per cent. of the explosions occurred from negligence on the part of the attendants; and on this account, whatever means might be adopted for examining boilers, he thought it would be impossible ever to succeed in entirely preventing explosions, although there could be no question that the number of them might thereby be reduced to a very great extent.

What he had himself found to be the cause of more trouble in the working of boilers than anything else, had been the occurrence of overheating of the plates, not from any deficiency of water, but merely from deposit upon the plates. Where the water contained 
carbonate of lime in considerable quantity, he had found it nearly impossible to keep boilers in good condition, especially if there were any grease or oil in the water, as was generally the case when the feed water was heated by the exhaust steam from the engine, the steam bringing over with it particles of grease and tallow from the cylinders; in such instances he had found it impossible to prevent leakage taking place.

Mr. F. J. Bramwell enquired why water containing carbonate of lime was more injurious to boilers when the feed water was heated by direct mixture with the exhaust steam, as in non-condensing engines, than when it was pumped from the hot well of an ordinary injection condensing engine; and whether it was more injurious than the water returned to a boiler from a surface condenser, which consisted of the condensed steam alone without any mixture of fresh water.

Mr. R. B. LoNGridge replied that the reason why water containing carbonate of lime was more injurious to a boiler when heated by the exhaust steam of a non-condensing engine was that, when so heated, it carried over a much larger proportion of grease into the boiler than was the case where the feed water was supplied from the hot well of a condensing engine. The same results occurred indeed with condensing engines, though not to the same extent; he had met with instances where the boilers of condensing engines had to be stopped time after time for repairs, and it had been impossible to keep them in order. Ultimately the only remedy had been found by feeding the boilers with fresh cold water, instead of from the hot well, and by blowing-off from the surface of the water in the boilers so as to get rid of the carbonate of lime; after that plan was adopted there had been no further trouble, and the boilers had worked for some years up to the present time without any trouble.

The Chatranas enquired whether in describing the effects of water containing carbonate of lime, a distinction was intended to be made between carbonate and sulphate of lime.

Mr. R. B. LongRidae replied that the sulphate of lime sank in the water and formed a hard scale, which was not so injurious to the 
plates; but the carbonate of lime being light rose to the surface, and mixing with any grease upon the surface of the water, gradually settled on the plates at the water level, and dried hard there, forming a thick coating and preventing the contact of the water; the plates consequently became red-hot in some cases, although there was abundance of water in the boiler.

The Chairman suggested the possibility of the injurious results having been produced by carbonate of magnesia, which was often present in water with carbonate of lime; it was the carbonate of magnesia he believed which rose to the surface of the water, while the carbonate of lime sank to the bottom. His own experience with boilers had been that carbonate of magnesia was more injurious to the plates than carbonate of lime; it was very commonly present with carbonate of lime, and where the two were present together it was easily mistakea for carbonate of lime. He enquired from what geological formation the water had been taken that was found so injurious in the boilers.

Mr. R. B. Longridae replied that one of the worst cases had been at Scarborough, where the boilers were supplied with water from the limestone. The material deposited upon the boiler plates at the surface of the water had been analysed by Dr. Roscoe, Dr. Angus Smith, and other chemists, and had been found to be principally carbonate of lime; it contained of course some carbonate of magnesia, but the greater proportion was carbonate of lime.

The Chatrman said the results of chemical analysis must necessarily be accepted; but from the large quantity of carbonate of magnesia known to be contained in the Scarborough water, he was inclined to think the injurious action upon the boiler plates was really to be attributed to this, rather than to the carbonate of lime.

Mr. T. R. Crampton observed that the question of corrosion in steam boilers was a most important one, and in consequence of the very serious results to which corrosion had led he considered the great object to be aimed at was to prevent it from taking. place at all, whatever the nature of the water employed. Commercially he did not think it was advantageous to work high-pressure condensing engines at so high a pressure as was now often 
employed; and notwithstanding that in surface-condensing engines the exhaust steam was all returned to the boiler, he believed it was practicable effectually to prevent any corrosion occurring in the boilers. He had himself lately succeeded in accomplishing this object with a pair of small condensing engines, employed for pumping water, having upright cylinders of 18 inches diameter and 20 inches stroke; steam was supplied by two small Cornish boilers, and by means of surface condensers the same water was used over and over again, and the vacuum regularly obtained was as much as $29 \frac{1}{2}$ inches of mercury. These engines had now been at work nearly four years, and particular care had been taken to prevent any grease getting into the boilers; the pistons were made practically steam-tight by a number of light rings presenting a small rubbing surface against the cylinder, and the stuffing-boxes were packed with a packing made of cotton with a little asbestos and French chalk, so that no grease whatever was' supplied either into the cylinders or the stuffing-boxes for lubrication. The water in the boilers was from the chalk formation in Kent, and had only twice been blown off with an interval of two years; the water had never been changed except on these two occasions of blowing off, and the leakage that took place was very small indeed; on looking into the boilers about two months ago, after they had been constantly at work about fourteen months since last blowing off, he had found the surface of the plates looked quite black, and showed no signs of corrosion or pitting in any way. The reason he considered was that no fatty acid had been able to find its way into the boiler, as no grease at all was used in the cylinders; and he believed if any grease had been used in the cylinders it would have been impossible to work the boilers with the same success. In order to do altogether without grease in the cylinders it was only necessary in practice that the cylinders should be placed upright, in which position the friction was least; and the pistons could be made effectually steam-tight by baffling the steam with a number of light packing rings, which together presented but a small extent of rubbing surface and caused so little friction as to dispense with lubrication by fatty matter. The engines he had described were working at 
10 horse power each, and the consumption was $2.8 \mathrm{lbs}$. of coal per horse power per hour, 8 lbs. of water being evaporated per lb. of coal. The whole of the cylinder surfaces were carefully steamjacketted, and all steam surfaces well lagged. The pressure of steam employed was $30 \mathrm{lbs}$., and the effective expansion was five times. In the same engine he had used $60 \mathrm{lbs}$. steam with a proportionate degree of expansion; but with no better results in economy, as there were losses attending high expansion that nentralised the gain. These very successful results showed that condensing engines could be advantageously worked with surface condensers, without grease either in the cylinders or the stuffingboxes, and without corrosion in the boilers; and he thought accordingly that if a little more attention were paid to this subject by the users of boilers, it would tend greatly to prevent many of the accidents at present occurring.

Mr. D. Adamson remarked that the numerous examples of explosions given in the paper clearly illustrated the fact that the first rupture in a boiler was the important thing to be provided against; and he considered there was great room for the further application of sound mechanical principles, for preventing one part of a boiler pulling against another in consequence of the existence of ufbalanced strains or unequal distribution of the heat. Wherever the greatest strain occurred in a boiler, it should be met by a proportionate increase in the strength of the structure, so as to give an equal degree of security in all the parts; but he thought it was a mistake to aim at security by insisting upon some particularly high tensile strength in the boiler plates employed, because this was necessarily accompanied by a degree of brittleness and hardness in the iron which rendered such plates unsuitable for boiler work. The shell of a boiler should not be subjected to a greater tensile strain he considered. than 4 tons per square inch of section; and therefore a cylindrical boiler of 7 feet diameter, made of plates 7-16ths inch thick with double-rivetted joints for the longitudinal seams of the boiler shell, was quite safe for working at 60 lbs. pressure, without coming near that limit of strain. Where there was much liability to 
corrosion however, he thought it was preferable to take 2 tons per square inch of section as the safe limit of tensile strain. As the seams of boilers were the parts where the deterioration of strength by corrosion, leakage, and wear and tear mainly took place, it was important that their number should be reduced as much as possible; a considerable advance had indeed been already made in this direction, the number of seams in Cornish and Lancashire boilers having originally been $2 \frac{1}{2}$ times as great as in boilers of the same class constructed by himself at the present time; but a further material reduction in the number of joints might still be effected by the use of larger plates than had hitherto been generally employed. In a boiler $8 \mathrm{ft} .6$ ins. diameter which he had recently made under the advice of Mr. George Salt for Messrs. Ambler's works at Bradford, to work at $100 \mathrm{lbs}$. pressure, the entire circumference of the shell was made of a single large steel plate 27 feet long and $3 \mathrm{ft}$. 3 ins. wide, having consequently only a single longitudinal double-rivetted joint in each of the lengths of which the boiler barrel was composed; these plates, weighing $16 \mathrm{cwts}$. each, had been made for the purpose at the Bolton Iron and Steel Works, and similar large steel boiler-plates were being rolled also at the Barrow Works. What was wanted in boiler plates was a uniform quality of metal and regular thickness, with a considerable degree of flexibility; if the iron was of irregular quality or the plates irregular in thickness, a boiler would destroy itself from these defects sooner than it would be destroyed by the action of the fire. The punching of the rivet holes had been found to reduce the strength of boiler plates as much as 21 per cent. in the case of steel plates, and nearly as much in Low Moor plates, but not more than 7 or 8 per cent. in the less stubborn Staffordshire plates; but even the last amount of reduction was too much to lose by the destructive process of punching; and he therefore made a practice of drilling all the rivet holes through both plates together in the boilers that he constructed, so as to avoid impairing the strength of the plates, and to enable the joints to go together with complete accuracy.

In boilers having internal flues, the external pressure would be certain sooner or later to collapse the flues if there were the 
slightest departure from the true circle in their shape; and it was therefore important not to trust to the permanency of the correct structural form, but to strengthen the flues irrespectively of their configuration, and to make some provision for limiting the distance over which a collapse if it did occur could extend, particularly in the case of long flues. Previously to the experiments of Sir William Fairbairn in reference to the subject of collapse of tubes under external pressure, he had himself already made about two hundred boilers having the flues strengthened by being put together with flanged seams, whereby flues 30 feet long were divided into nine or ten distinct lengths, and were thus supported rigidly at frequent intervals, so that if a collapse ever did occur it would be restricted to the short portion of flue between two of these supporting rings. The liberation of the steam pressure would thus be comparatively slow, and the disastrous effects consequent upon the suddenness and magnitude of ordinary explosions would be avoided. In internally-fired boilers, it was desirable that all joints formed by two thicknesses of plates should be removed from the action of the fire, and this could only be accomplished by using flanged seams for the circular joints of the flues, in which case the double thickness of plates was immersed in the water; and if steel plates were used with the longitudinal seams double-rivetted, care should be taken to keep these seams below the action of the fire, on account of the unequal strains that would be occasioned by double and single thicknesses of plates. Another point of construction, which had been attended with much practical difficulty, was the connection of the flat ends of boilers to the shell and the flues; and his own experience had led him to the conclusion that it was a mistake to rivet thin flue plates to the thicker end plates without increasing the thickness of the flue ends to the same thickness as the end plates themselves. The gusset stays uniting the end plates to the shell of the boiler should not come nearer the flues than 8 or 9 inches, measuring from the outer circumference of the flue; the difficulty was to control in the best way the springing of the end plates under pressure withont rendering them too rigid, and this was the mode of construction which he had found 
the most successful in accomplishing that object. In the testing of boilers he considered it was very important to take care that the testing strain was not carried so high as to produce any permanent set in the iron of the plates. The plan he had adopted for testing boilers as to any permanent expansion had been to stretch a thin steel ribbon round the boiler shell, and draw a fine straight line across the two ends of the ribbon where they came together, and then observe whether the two lines coincided when the pressure was removed after the testing; by this means he had found that up to a tensile strain of 7 tons per square inch of section of metal the elasticity of the iron was not exceeded, and on the pressure being removed the boiler shell came back to its original dimensions without any permanent set having taken place.

He could confirm what had been said as to the great trouble experienced from carbonate of lime or carbonate of magnesia uniting with any grease in the boiler, and forming a thick "floury" coating over the plates, which effectually kept the water away from them wherever it settled upon them. When a quantity of this sediment, commonly known as "flour powder," was placed in a ladle and heated, a great quantity of grease contained in it was rapidly made manifest; and he believed it was the mixture of the grease with it which enabled it to spread itself along the sides of the boiler at the water level and adhere to the plates. The evil thus occasioned by the presence of grease in boilers might be considerably mitigated, he considered, if cylindrical balanced valves were more generally used, instead of the flat slide-valves commonly employed in steam engines; by that means the quantity of lubricating material required for the valves would be greatly reduced, and less grease would be carried into the boiler when the feed water was heated by the exhaust stean. Where good water was hard to get for boilers and surface condensation was also difficult, he thought it might be desirable to work at a higher pressure of steam, even up to as much as $130 \mathrm{lbs}$. per square inch, in order to get the greatest advantage out of a boiler; but under ordinary circumstances he considered 80 to $100 \mathrm{lbs}$. was quite as high as was advisable for the regular working pressure in stationary steam boilers. Some of the 
most disastrous explosions of boilers had occurred from want of uniformity in the temperature of the water in internally-fired boilers, where the water had remained nearly cold at the bottom of the boiler below the fire during the time that the boiler was standing before commencing work in the morning; and he thought therefore it was a very desirable precaution in such boilers to blow off a quantity of water from the bottom during the time occupied in getting steam up and before commencing work in the morning, in order to stimulate the circulation of the water and distribute a more equal temperature throughout the boiler.

Mr. H. T. Ferguson said he had taken some interest in boiler explosions in Cornwall, and having had opportunities of examining several boilers that had exploded there, he had in every instance found the explosion had resulted from sheer neglect. The clumsy screw patch shown in Fig. 35, Plate 59, was a specimen of the dangerous way in which he had seen boilers patched in that district. During the past year he had visited eight explosions; and in one case, after having obtained permission to photograph an exploded boiler, he was not allowed to proceed to do so, as the owner objected to the bad state of the boiler being made known. Many of the explosions in Cornwall occurred from the want of glass water-gauges, or some other means of ascertaining the height of the water in the boiler besides the two gange-cocks now in use.

Mr. F. A. PAGET remarked that Cornwall illustrated the weak side of voluntary inspection, because the boilers were there scattered so far apart that the expense of inspecting them would be considerably increased as compared with Lancashire; and he thought therefore voluntary inspection would not be likely to prove effectual in such a district as Cornwall, and that some other plan would have to be adopted there. In reference to the internal corrosion of boilers, he believed that with steel boilers, on account of the homogeneous nature of the metal, no instance had been met with where the plates showed that peculiar form of corrosion called "pitting," which had frequently proved a source of danger in ordinary iron boilers. 
Mr. W. Ford Sмгтн believed the introduction of distilled water with the feed water was an effectual means of preventing deposit in boilers, and he had recently witnessed an instance where distilled water had been introduced with the feed water into a boiler and there had been found to be a very small amount of incrustation in consequence. In this case, which had been under his own notice for eight years past, a double-flued boiler was supplied with the Manchester town water and rain water, and the exhaust steam with all the grease contained in it was blown into a cistern, from the bottom of which the feed water, probably free from grease, was taken to supply the boiler. The two flues were both perfectly free from incrustation, and seemed as clean as when first put to work, which he believed was mainly due to the use of the distilled water from the exhanst steam. The incrustation of boiler plates by deposit from the water was a very important point in connection with boiler explosions, and it was most desirable that it should be prevented as much as possible.

Mr. L. OLRICK concurred in the remarks which had been made as to the great evils occasioned by the presence of bicarbonate of lime, commonly known as carbonate of lime, in the feed water supplied to steam boilers; and one method that had been adopted for preventing the formation of deposit consisted in removing the carbonate of lime from the feed water by Dr. Clark's process of precipitation. This plan had been applied with success to a boiler at Bury St. Edmunds, where the water supplied for the feed contained 30 grains of carbonate of lime per gallon. This water was pumped into a tank 6 feet high and 2 feet diameter, and from another tank of smaller diameter lime water specially prepared was constantly running into the large tank, which had the effect of precipitating the carbonate of lime originally contained in the feed water, by the incoming lime disengaging the carbonic acid contained in the bicarbonate, and thus converting the soluble bicarbonate into insoluble carbonate of lime. The greater part of the lime sank down to the bottom of the mixing tank, and the water, which was then of a slightly milky colour and containing the flakes of lime, was drawn off near the bottom of the tank, and filtered into 
another tank partially flled with small pieces of coke as a filtering material, through which the water ascended slowly to the top of the tank, where it was drawn off for use in the boiler. If the water was required for drinking purposes, it was, in addition to the above filtration, passed through a second filter of animal charcoal, by which the organic impurities contained in the water were removed. Means were also provided for removing the coke periodically from the filtering tank when it had become charged with lime, and replacing it with fresh coke, by having a loose cylindrical casing to contain the coke inside the filtering tank. In this way the filtration was so completely effected that during the two years that this process had been in operation no trouble whatever had been experienced with the boiler, which worked free from danger, as there was an absence of any hard scale on the plates. The boiler was opened once in every three months, and a little dust that had accumulated was swept out, which was all that had accumulated from the water during that time of working. Previously a hard scale of an inch thickness used to be formed in three weeks' time, which had been very difficult to remove and had necessitated a great additional consumption of fuel and loss of time in cleaning.

An instance of the danger that might be occasioned by deposit from the feed water had come under his notice in the case of a well made Cornish boiler in London. The feed pipe was brought in at the front end of the boiler and carried down to the bottom, delivering the feed underneath the furnace in the flue; and within a short time of being set to work, the crown of the flue collapsed over the fire, fortunately not sufficiently to cause an explosion. It was then repaired with a new Low Moor plate, but the very same accident happened a second time soon after its being started again. It was then surmised that this occurrence must be owing to the place at which the feed was introduced, and that although the feed water entered at the bottom the circulation would cause it to rise at once to the top, and the sediment would be enabled to deposit itself there upon the top of the flue; and it was accordingly found that the deposit of sediment at this part, although thin, was sufficient to prevent the water from touching the plate, which had thus become 
so much softened by the overheating as to be collapsed by the steam pressure. The feed pipe was afterwards continued horizontally along the water level in the boiler to a distance of 3 feet beyond the fire bridge, and a "rose" or nozzle was put on the end of the pipe, having a number of small holes to distribute the feed water thoroughly on entering the boiler; and no further collapse of the flue had since taken place. In this instance the feed water was largely charged with carbonate of lime, causing an extremely hard and impermeable deposit in the boiler. He thought however that, instead of pumping into steam boilers water impregnated with all sorts of impurities which would form thick layers of scale on the plates, and then removing this by means of hammers or boiler compositions, it would be far preferable in every case to adopt the simple plan of cleansing the water completely of all deposit before it entered the boiler. This might be accomplished in a variety of ways, and would be attended with a considerable saving in fuel, while much of the danger ordinarily incurred in the working of steam boilers would be avoided.

Mr. W. Richardson thought the observations made in the paper and illustrated by the diagrams exhibited, in reference to facility of examining steam boilers, were likely to mislead a little; from his own experience he considered that such a construction and mode of setting as were shown in Fig. 42, Plate 60, though having the advantage of rendering the boiler easy to examine, were not conducive to its safe working, because having once had a number of externally fired boilers he had found great difficulty in keeping them in a safe condition, on account of their being liable to the formation of deposit over the fire, or to rupture by contraction if culd water ever entered the boiler. Also in Figs. 46 and 47 , in which the external flues were represented as made so large that a man could enter them upright, he did not see how any ordinary chimney could be capable of producing draught enough through such large flues to render the combustion sufficiently active for raising steam; and therefore, though flues of large sectional area would be advantageous in one respect, they would be bad in regard to the regular working of the boilers. 
The means of providing for the use of impure feed water for steam boilers was a subject of very great importance. At Oldham, where Messrs. Platt's works with which he was connected were situated, the town stood on a high hill, from 500 to 800 feet above the sea level, with no river near; and the only water supply was obtained from higher ground at a considerable distance, and was so limited in amount that there was not more than was required to supply the town for domestic purposes; and they were therefore obliged to obtain their supply of water from the foul water running down the drains. In order to purify this very dirty water sufficiently to render it in the first instance suitable for condensing purposes, they had constructed a series of three reservoirs, the first for the earthy matter's to settle down, the second supplied from the overflow of the first, and the third from the overtlow of the second. The supply of injection water for the condensers was taken from the third reservoir, and was returned into the second. The boiler feed was taken from the hot well, and was forced through a number of vertical cast-iron vessels, strong enough to bear an internal pressure of $100 \mathrm{lbs}$. per square inch, the regular boiler pressure being $75 \mathrm{lbs}$. Midway in the height of each vessel a layer of calcined bones was placed upon a perforated plate or grating, and the dirty water from the hot well was driven upwards from the bottom through the mass of bones by the feed pump; in this way it was so thoroughly cleansed of all impurities as to be fit to pass direct into the boiler from the top of the purifying vessel. The water from the hot well was so dirty, that the layer of bones would become choked with sediment and filth in only half a day; and it was therefore necessary to cleanse them twice a day, which was done in the dinner hour and at night by blowing steam down from the top in the opposite direction through the bones, by which means they were thoroughly cleansed and made ready for use again. The thickness of the layer of bones was about 3 feet, and after a year's constant working they were found to have settled down only about $1 \frac{1}{2}$ inch. This was the plan they had adopted for their condensing engines, for which a continuous fresh supply of clean feed water had to be obtained from the foul water of the drains. 
For the non-condensing engines, in order to get back heat and water from the exhanst steam and feed the boilers with clean hot water, a supply of water was taken from the last of the settling reservoirs into a covered cistern 6 feet long by 3 feet wide and 6 feet deep, the height of the water in the cistern being regulated by a ball cock so as to be kept 9 inches below the cover. On the top of the cover stood at one end a vertical cylindrical feed-water heater, 30 inches diameter and 12 feet high, fitted with tubes like a locomotive boiler or a surface condenser; and on the other end of the cistern cover stood a vertical pipe 20 inches diameter and 30 feet high, open to the atmosphere at the top. A circulating pump lifted the water from the cistern to the top of the vertical pipe, within which it then fell down in a shower back into the cistern again. The exhaust steam discharged from the high-pressure engines passed down through the inside of the tubes in the feed-water heater, then over the surface of the water in the cistern, and escaped up the vertical pipe, where it met the falling shower of water from the circulating pump. By this means the water in the cistern became hented up to $170^{\circ}$ Fahr., and was supplied at that temperature to the boiler feed-pump, by which it was forced through a bone filter, like that already described of the condensing engines, and thus purified was then made to pass outside the tubes of the feed-water heater, and entered the boiler at the temperature of $210^{\circ} \mathrm{Fahr}$. In this way a supply of clean feed water was obtained, heated up almost to the boiling point, from the exhaust steam discharged by the noncondensing engines. With this arrangement for purifying the feed water, the boiler was now only cleaned at holiday times, four times a year; but before adopting this method, the boiler used to have to be cleaned every week or fortnight, and was very seldom allowed to run more than the fortnight. The quantity of deposit got out now that the boiler was cleaned four times a year was not so much at each time of cleaning as was formerly got out in a month; and the saving effected in the coal consumption and labour had paid the interest of the outlay expended in thus getting over the difficulty of obtaining clean feed water for the boilers from a supply of dirty water. 
The Chairman enquired what kind of water it was that the town was supplied with, and what was the size and construction of the boilers, and the length of time they had been working on that arrangement.

Mr. W. Richardson replied that the water was moss water obtained from boggy ground on hills at some distance from Oldham and above the cultivation level. The boilers were $6 \mathrm{ft}$. 6 ins. diameter and 30 feet long, with a single flue $3 \mathrm{ft} .10 \mathrm{ins}$. diameter extending a length of 23 feet, beyond which they were multitubular for the remaining 7 feet. Some of these boilers had now been working regularly for nine years, and at the present time they had forty boilers in use, all of which, with the exception of two, were made of steel plates; there had been no difficulty or extensive repairs with them, and they continued working quite satisfactorily.

Mr. W. Ford Sмrтh enquired what was the appearance of the boilers inside, after working with the feed water cleansed in the manner that had been described.

Mr. W. Richardson replied that there was very little incrustation upon the plates. In addition to cleansing the feed water, they used also a vegetable substance obtained from Finland, which he understood was the decayed root of a tree; this was boiled down with a little soda and potash, and a small quantity of the liquid decoction was supplied into the boilers from an elevated cistern, along with the feed water. This was found to prevent any fixed deposit of hard scale forming upon the plates, and the only deposit that took place in the boilers was a little mud deposit, which was blown off regularly at the mud-cock. In all these boilers the practice was to introdnce the feed water just below the low water line, instead of at the bottom of the boiler; and another precaution which had been found very advantageous was to make the fecd pipe travel such a long distance inside the boiler, that the feed water should become heated to the temperature of the water in the boiler, before being discharged from the pipe. Previous to adopting this plan, they had had many plates fractured at the bottoms of boilers that were externally fired, in consequence of the colder feed water falling 
directly to the bottom, and thereby causing the bottom plates to contract suddenly and to crack and leak. In some cases they had put a length of as much as 30 feet of feed pipe inside the boiler, and this had been completely successful in preventing fracture or leakage of the bottom plates.

Mr. W. Bouch observed that the paper which had been read, and others upon the same subject on previous occasions, had quite done away with the fanciful theories formerly entertained respecting the canses of steam boiler explosions, and had brought out clearly the simple fact that explosions resulted only from the rupture of material which was not strong enough to bear the strain put upon it. As the disastrous effects attending an explosion were due to the sudden liberation of a confined volume of water heated to a very high temperature, some boilers had been specially constructed with the object of reducing to a minimum the volume of water contained in them, and raising the proportion of heating surface to a maximum, so as to enable the boilers to maintain the required production of steam from the small quantity of water. In such boilers the sudden liberation of the contents by the failure of any part could take place without any serious consequences, as was the case in locomotive and other multitubular boilers, where the bursting of a tube was attended with none of the disastrous results of a boiler explosion. $\mathrm{He}$ thought therefore that the principle of the locomotive boiler might advantageously be applied for stationary boilers to a much larger extent than was at present the case. Prior to the year 1849 he had experienced much difficulty in locomotive boilers of the old Stockton and Darlington class, with internally-fired flues, from the detrimental effects occasioned by concentration of the heat upon particular portions of the flues; and this had led him at that time to develop, in conjunction with Mr. Adamson, the flanged five, strengthened at intervals along its length by flanging the plates outwards at the circular joints and inserting a stiffening ring to which the two plates at each joint were rivetted. The application of this flanged flue had since then been very successfully and extensively carried out by Mr. Adamson for all stationary boilers having flues subjected to external pressure. In the working of locomotive boilers 
his experience was that it was not safe to keep them in full work longer than six years without a thorough examination of the tubes, firebox, and shell, the tubes requiring to be all taken out for this purpose. It was true that in particular cases there might be evidence that the extreme measure of pulling the tubes out was not then necessary; but as a general rule, when an engine had attained that age and had been working about 100 miles per day, it ought not to be allowed to continue running until it had undergone a very thorough examination in that manner.

Mr. F. J. BRAMweLL alluded to the "quicksilver engine" that was put to work in two steam vessels by Mr. James Howard in London about twenty-five years ago, in which no more water was contained in the boiler at any one time than was required for one stroke of the engine; and when the engine was standing there was not any water in the boiler at all. The boiler was made with a donble bottum, and the space between the inner and outer plates was filled with an alloy of quicksilver and lead, which was kept heated to a high temperature by the fire directly underneath; the inner boiler plate had deep indentations in it, dipping down into the alloy, so as to increase the extent of water-heating surface. The feedwater was injected into the boiler at each stroke of the engine by the feed pump, the quantity injected being accurately adjusted to the exact amount required for a single stroke; and it was distributed all over the heated bottom of the boiler, so as to be flashed off instantly into steam. With such an arrangement, if a boiler explosion did ever occur, it would be attended with a very small amount of damage.

The Chalrman observed that the paper which had been read presented a very interesting condensation of important facts upon the subject of steam boiler explosions, and was very completely illustrated by the extensive series of diagrams exhibited; and it had elicited a discussion of great value. He proposed a vote of thanks to Mr. Marten for his paper, which was passed.

The following paper was then read:- 
Fig. 1. Cornish Boiler; exploded firm external corrosion. Length 22'4." Diam. 6'1." Southsea 1870.

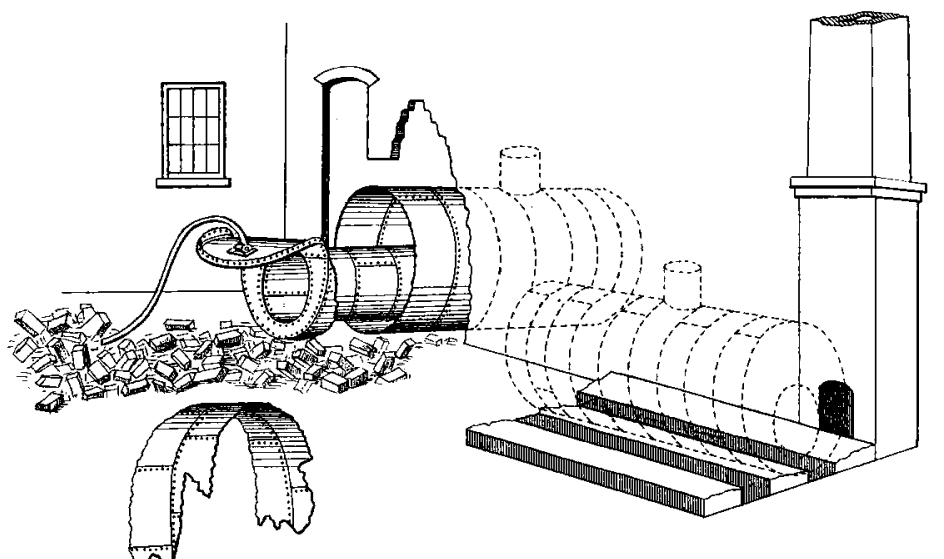

Fig. 4. Cornish Boiler;

Fig. 2. Lancashire Boiler, exploded from internal corrosion.

Length 32'0." Diarn. $8^{\prime} 0$."

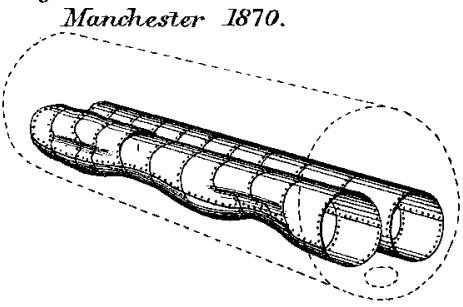
exploded from external corrosion. Length I4'6." Diam. 5'0." Accrington 1869.

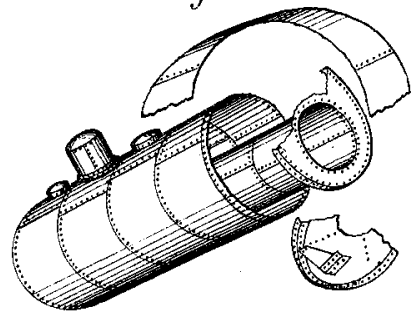

Fio. 3. Lancashire Boiler; exploded from external corrosion.

Length 22'0." Diam. 7'6." Chathan 1866.

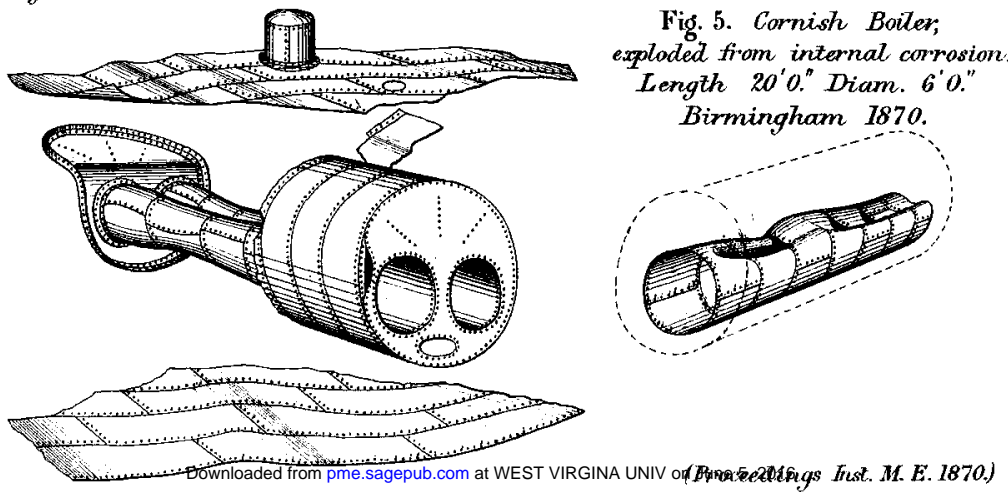


Fig. 6. Lancashire Boiler, externally fired, exploded from seam rip.

Length 30'o." Diam 7'o." Tamworth 1867.
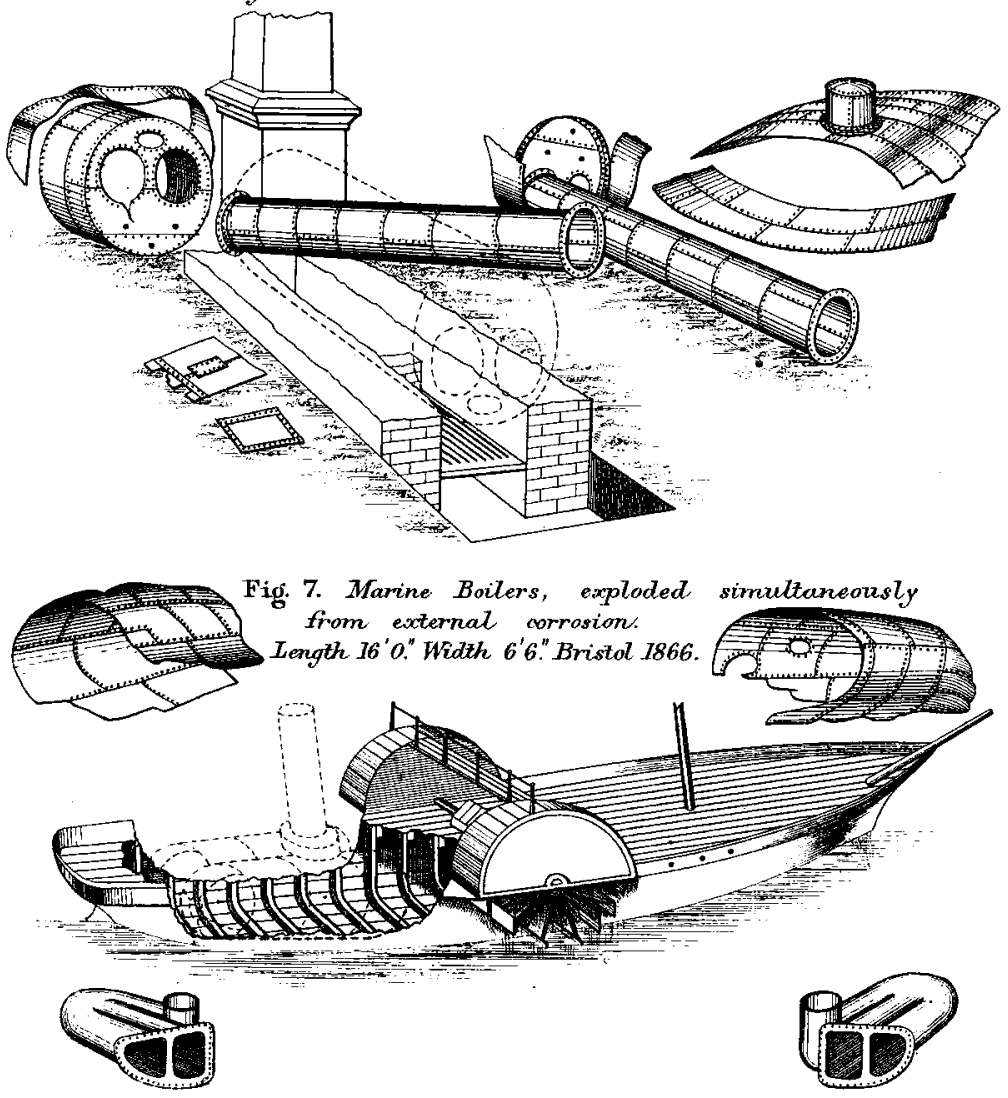

Overheated Boilers.

Fig. 8.

Plain Cylindrisal.

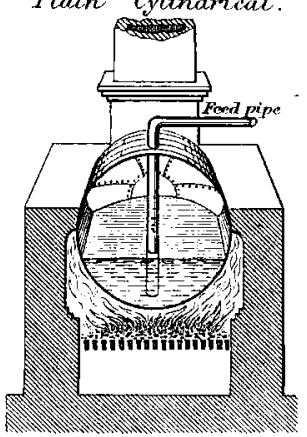

Fig.9. Furreace-Upright.

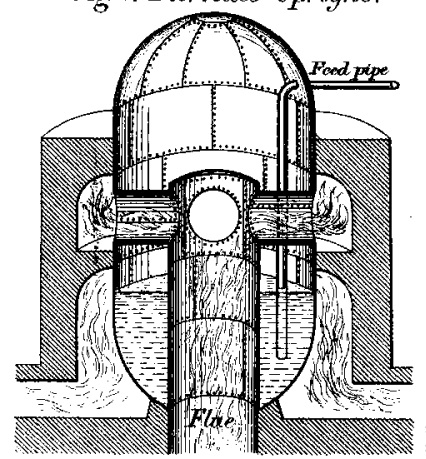

Fig. 10. Lancashire.

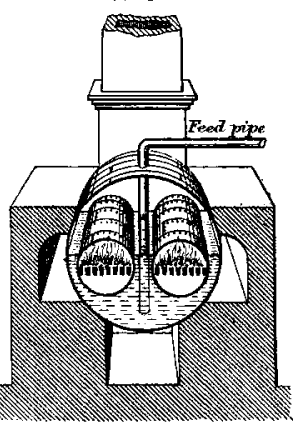

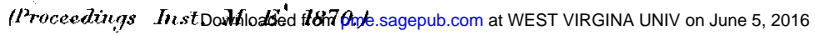


Fig.11. Four-Furnace Upright Boiler:

Height 22'0." Diam. 9'o."

Exploded from softening of plates

Stoke 1868.

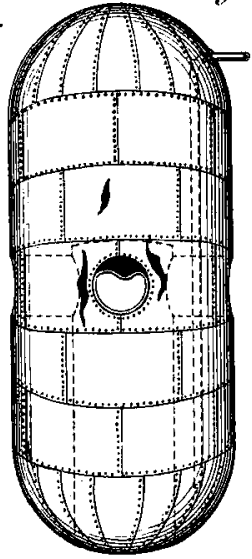

Fig. 14 Revolving Ray Steamer. exploded fron lurge weak mankole. Length 12 ' 6." Diam. 5' 0 ". Tanworth 1866.

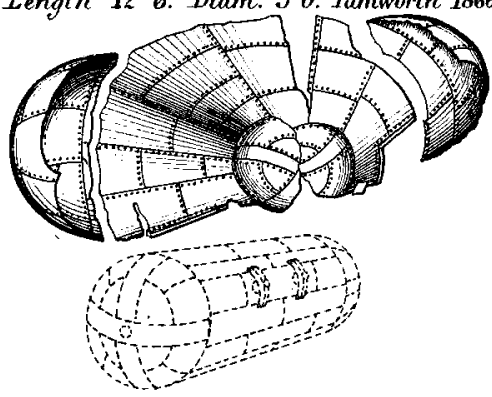

Fig. 12. Ploin Cylindrical Boiler: Lenglh 25'6." Diam. 5'6."

Willentiall 1868.

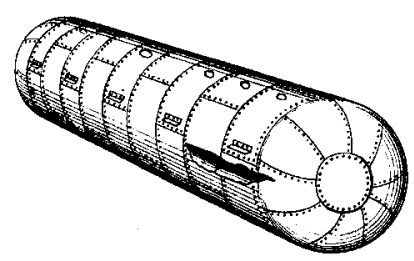

Fig. 13. Revolving Rag Steamer. exploded firm lange weak manhole: Lengthe $16^{\circ} 0^{\prime \prime}$. Diom. G' $0^{\prime \prime}$ Abingdem $16^{\prime \prime}$.

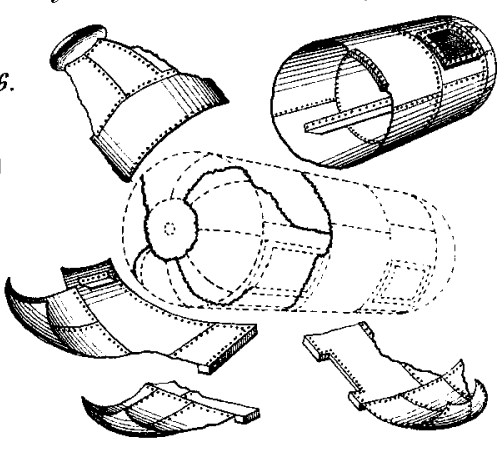

Fig. 15. Plain Cyl. Bailer, exploded from frequent repair. Lenglh 40'0.' Diam. 6'0."

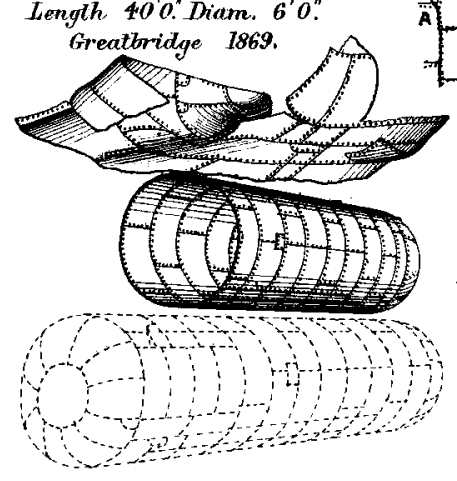

Fig. 16. Plain Cylindrical Rrilm.

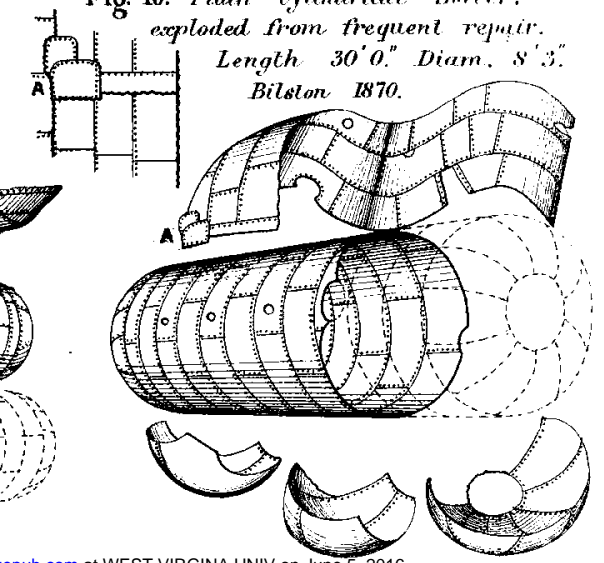

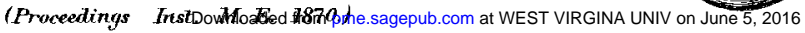


Fig. 17. Pluin Cylindrical Boiler, encploded from frequent repair. Length 34'O." Diam. 6'O". Westbrornwich 1870 .

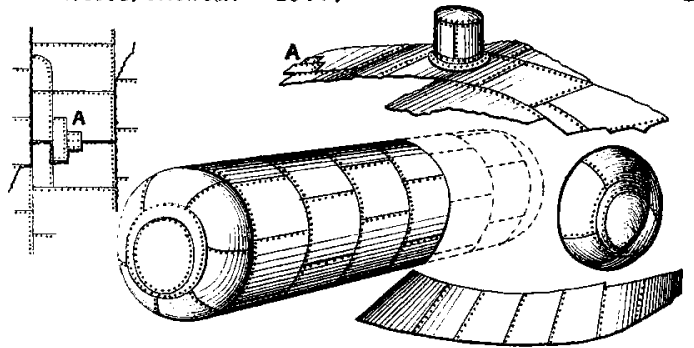

Fig. 18, Plain Cylindrical Boiler, cepploded from bad repair. Length $47^{\circ} 0^{\prime \prime}$ Diam 6' 0 ."

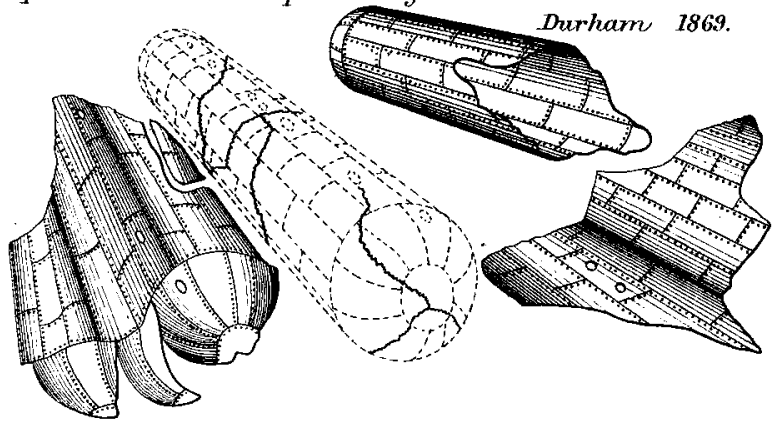

Fig. 19. T'wo-Fimace Vpright Boiler, exploded from extermal corrosion.

Height 22'0." Diam. 8'10." Wresham 1868.

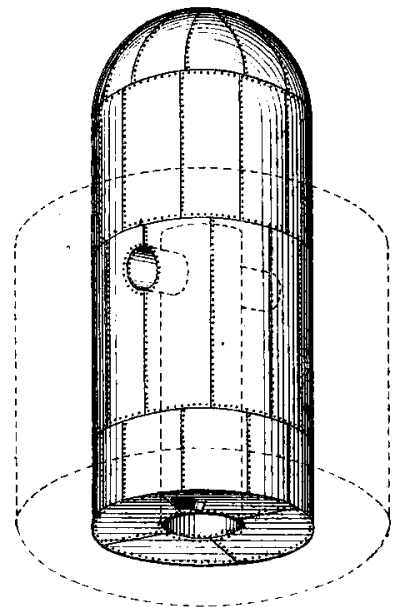

Fio. 20. Chimney Boiler, expladed firm internal corrosion. Height 4t" 4." Diarn. 6' 9." Liverpool 1868 . 
Fio. 21. Four-Fiunace tymight Boilen; croploded from external corrosion of centre tube.

Height $18^{\prime} o^{\prime \prime}$ Dioun. 9' 0 ."

Tule 4'9" dium. Iidsgrove 1870 .

Fig. 22. Four-Furnace tpright Boiter, exploded firom internal corrosion of centre tube.

Height 20'o." Diam. $10^{\prime} 0$."
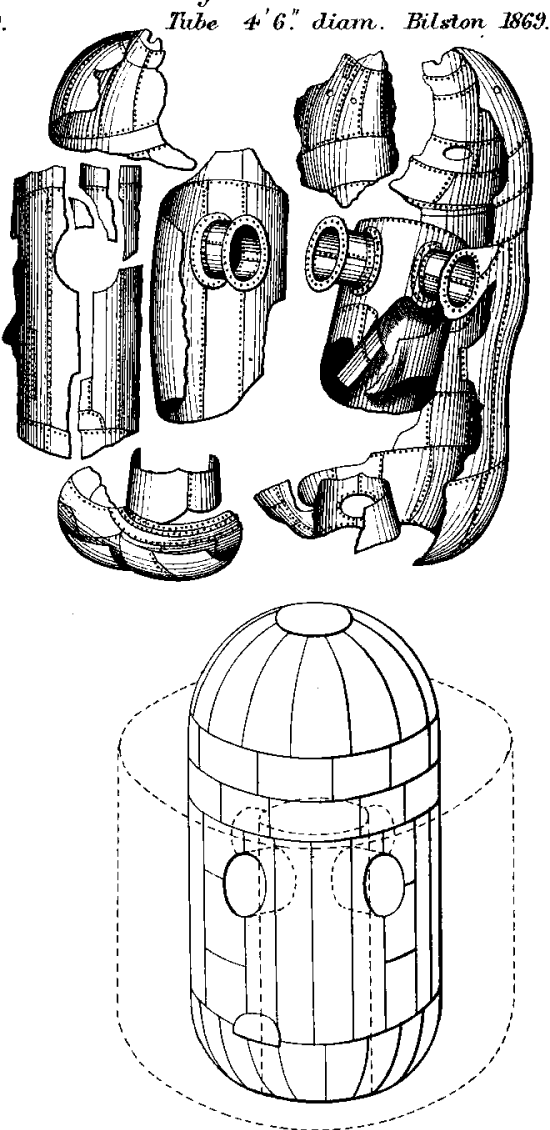

Fig. 23. Corniste Boiler. exploded from external corrosion.

Length 22'8." Diam. 6'0." Cornwall 1869.

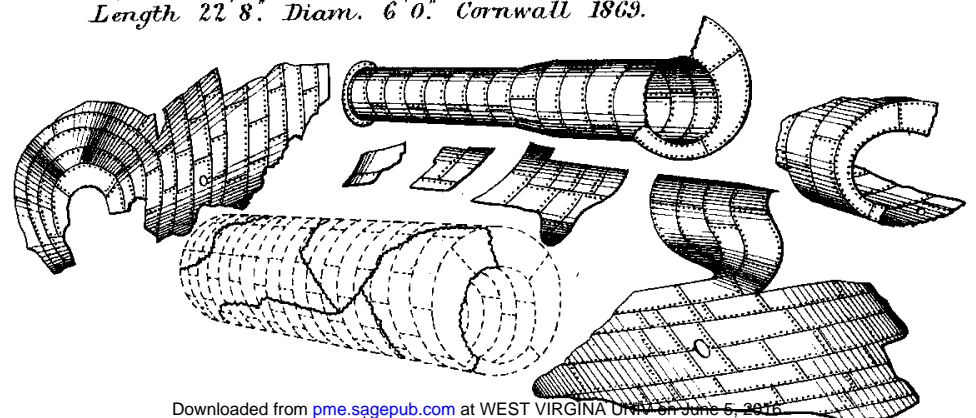


Fig. 24. Four-Furnace Upright Boiles: exploded firom seam rip.

Height 22' $0^{\prime \prime}$ Diam. 10'6." Moxley 1868.

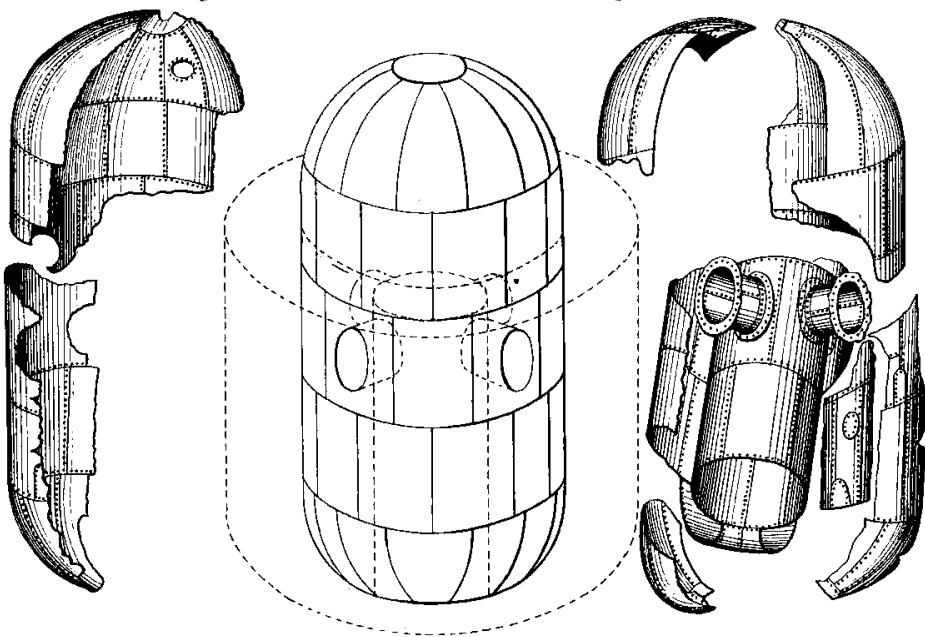

Fig. 25. Cornish Boiler. Length $32^{\prime} 0$." Diam $6^{\prime} 6$." $^{\prime \prime}$ Tube * $0^{\circ}$ diam. collapsed from weakness. Cornwall 1869.

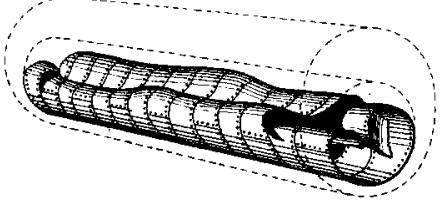

Fig. 27. Cornish Boiler. Length $15^{\prime}$ O." Diam, 5 '0." Tube oval at fire end. 2'11" wide, 2'6" high, collapsed from weakness. London 1868.

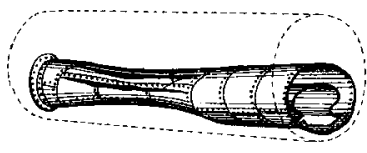

Fig. 26. Comish Boiler,

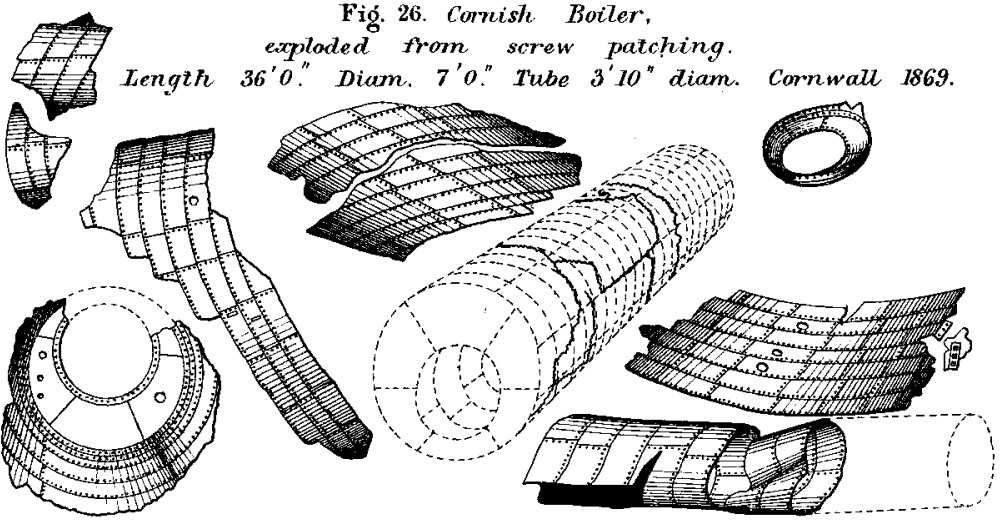

(Proceedings Inst. M.E. 1870)

Downloaded from pme.sagepub.com at WEST VIRGINA UNIV on June 5, 2016 
Fio. 28. Vertical Groe Boiler, expluded from external corrosion. Height $\boldsymbol{s}^{\prime} 3 . "$ Diam. 4' 4 ."

Firebox 6' 0 "high, 3' $6^{n}$ diam. Barking 1869.

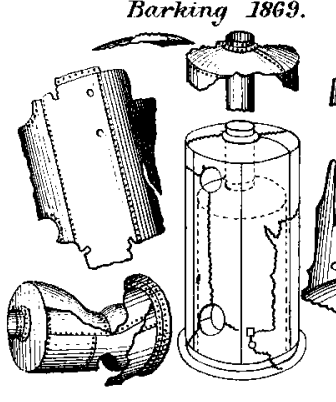

Fig. 30. Portable Boiler, exploded from bad manhole. Height 4'9." Diann. 2'3."

Birmingham 1868.
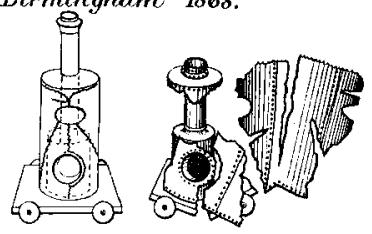

Fig. 29. Tertical Crane Boiler, exploded firm bad manhole. Height 5'6". Diam. 2'6". Liverpost 1866.

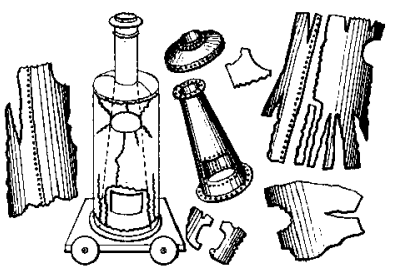

Fig. 31. Multizubular Boiler, exploded from bad manhole. Length $s^{\prime} 6^{\prime \prime}$. Barrel $6^{\prime} 0^{\prime \prime}$ long, $2^{\prime} 4^{\prime \prime}$ diam. Broseley 1869.

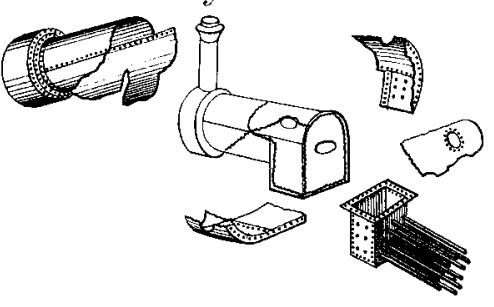

l'ig. 32. Elbu" Boiler, esploded from ends bulging through absence of stays. Lempth 22'0." Diarn, 5'0." Thibe 2'0"diam. Bilston 1868.

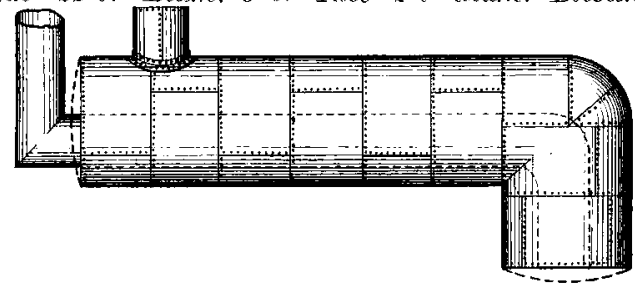

Fig. 33. Plain Cylindrical Boilor. altered from Breeches-Tube, exploded from absence of stuys. Lengthe $36^{\prime} 0$." Diam. 6'0." Iydrey 1869.

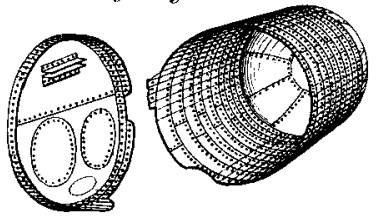

Fig. 34. Plain Cylindrical Boiler. altered from Cornish, exploded from insufficient stays. Length 25'o." Diam. 6'o."

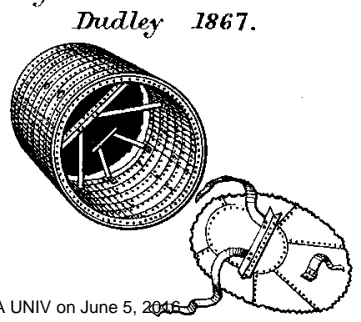


Figr 35. Platn Cylindrical Hoiter, exploded from extemat corrosion Length 21 '0". Diame. A 6 " Kidderminster $\quad 1869$

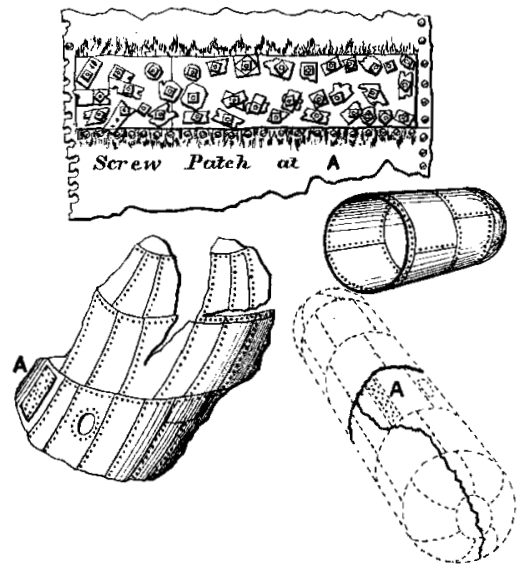

Fig. 38.

Plate injured by overheating.
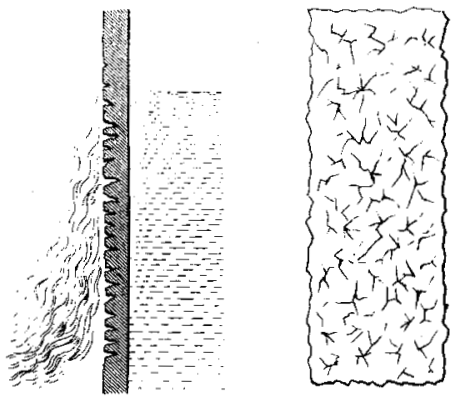

Rig. 39. No water

Fig. 40. Water-

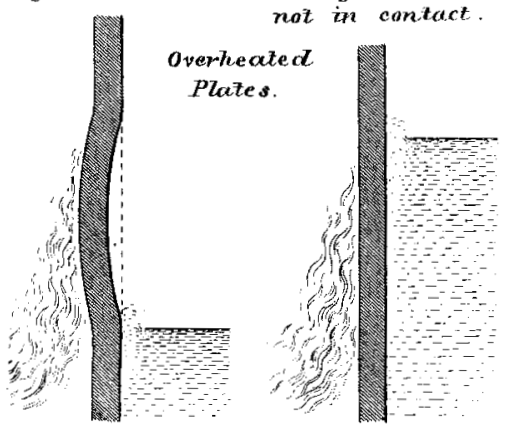

Fig. 36. Plain Cylindrical Boiler, exploded from frequent repair. Length 25'0" Diam. A'6" Westbromwich 1869 .

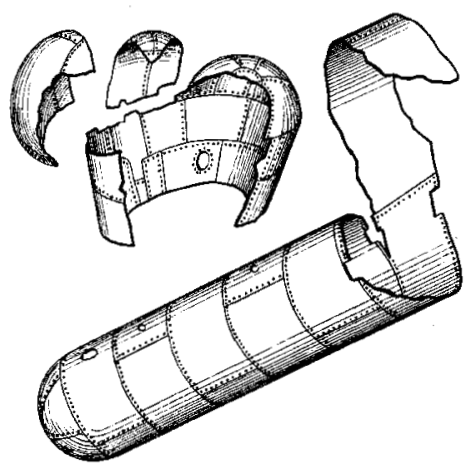

Fig. 37, Furnace-thrighz Boiler. flat crowr-plate to inside tube.

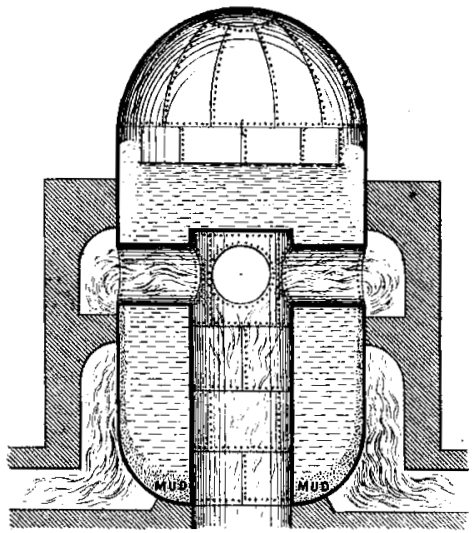

Fig. 41. Comish Boiler overheated, water not in corituct

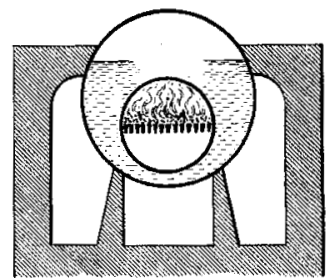

(Proceedings Imst. M. E. 1870.) 
Fid. 42. Plain Cylindrical Boiler, casy to examine.

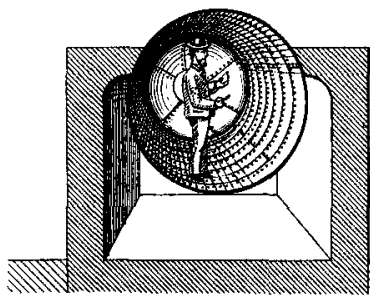

Fig. 43. Cornish Boiler. awkward to examine.

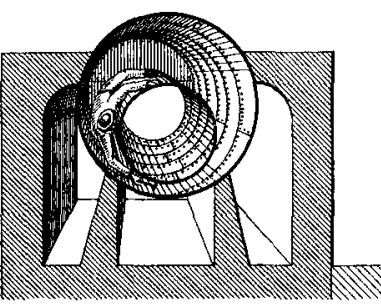

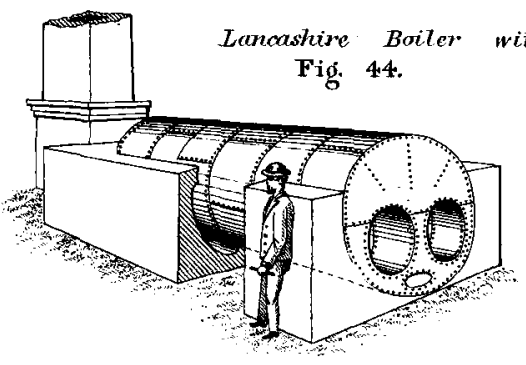

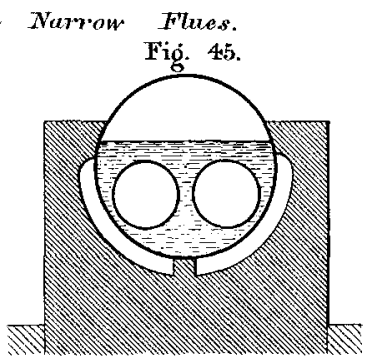

Lancashire Boiters.

Fig. 46. Wide Flues.

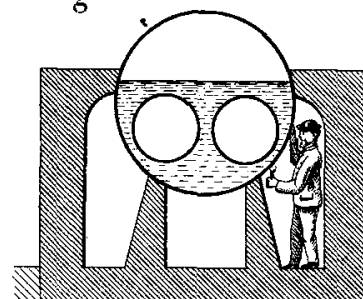
Fig. 47. Wide Flues.

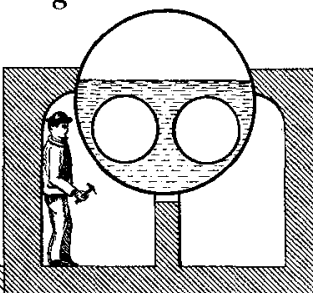

Fig. 48. Narrow Flues.

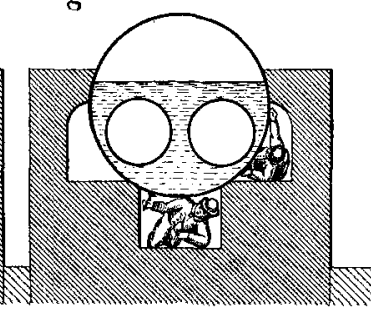

Cornish Boiler, with sight-holes in flues.

Fig. 49.

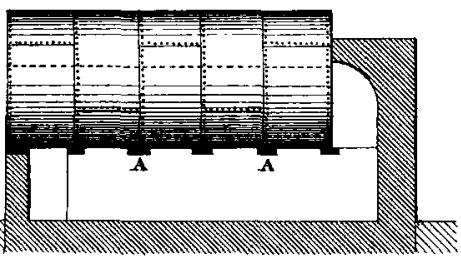

Fig. 50. Plan.

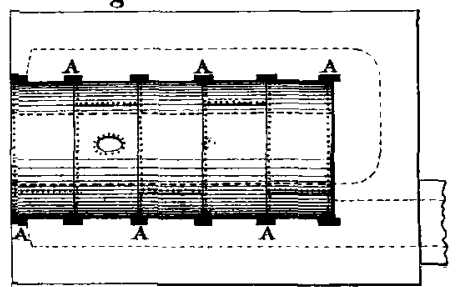

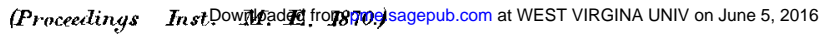


Fig. 51. Domeszic Boller, exploded from weak shape. $3^{\prime} 6 " \times 26^{\prime \prime} \times 1^{\prime} 0^{\prime \prime}$.

London $186 \&$,

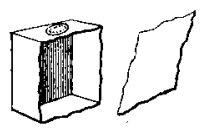

Fig. 53. Domestic Boiler, exploded from overpressuce. $74 " \times 1{ }^{\prime \prime} \times 10$, ."Monchester 1869 .

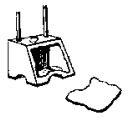

Fig. 56. Multitubular Boiler, exploded from overpressure, safety-valve tied down. Lengzh 6'O" Diam. 2 'O". Lynn 7867 .
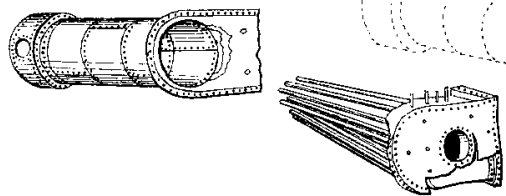

Fig. 57. Marine Boiler, exploded from corrasion. Length $17^{\prime \prime} 0^{\prime \prime}$ Height $15^{\prime} 0$ ". Yormouth 1869 .

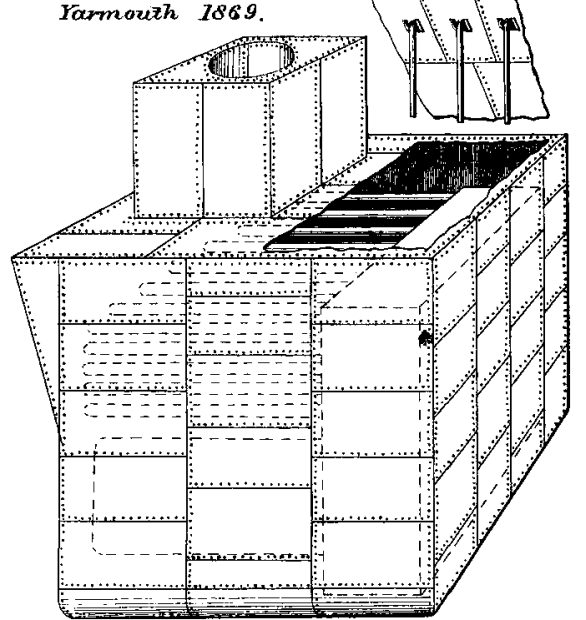

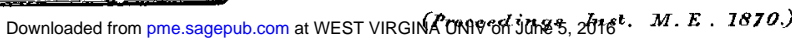

Fig. 52. Domestic Boiter, exploded from overpressure. $12 " \times 12 " \times 73 "$.

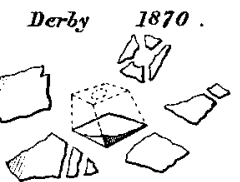

Fig. 54. Domestic Boiter. exploded from bod weld. $26^{\prime \prime} \times 2^{\prime} 0^{\prime \prime} \times l^{\prime} 1$ '. Sheffield 7870 .

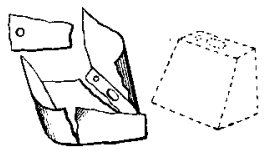

Fig. 5 8, Scale and Mud.

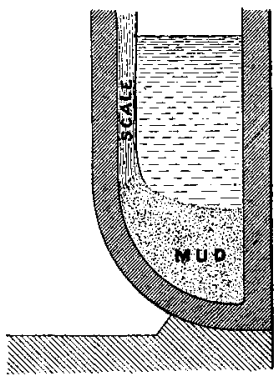

Fig. 59 .

Two-Furnace Vpright Boiler, exploded from intense flame. Height $21^{\prime} 0$ " Diam. 7'o".

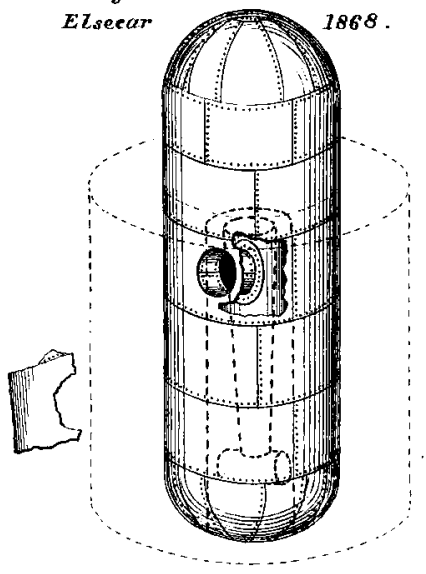

